\title{
A new MIS 3 radiocarbon chronology for Mochena Borago Rockshelter, SW Ethiopia: Implications for the interpretation of Late Pleistocene chronostratigraphy and human behavior
}

\author{
Authors \\ Steven Brandt ${ }^{1}$ \\ Elisabeth Hildebrand ${ }^{2}$ \\ Ralf Vogelsang ${ }^{3}$ \\ Jesse Wolfhagen $^{4}$ \\ Hong Wang ${ }^{5}$ \\ ${ }^{1}$ Department of Anthropology, University of Florida, 1112 Turlington Hall, Gainesville, FL \\ 32611 USA; sbrandt@ufl.edu \\ ${ }^{2}$ Department of Anthropology, Stony Brook University, Stony Brook, NY 11794-4364 USA; \\ elisabeth.hildebrand@stonybrook.edu \\ ${ }^{3}$ Institute of Prehistoric Archaeology, University of Cologne, Bernhard-Feilchenfeld-Str. 11, \\ 50969 Cologne, Germany; R.Vogelsang@uni-koeln.de \\ ${ }^{4}$ Department of Anthropology, Stony Brook University, Stony Brook, NY 11794-4364 USA; \\ jesse.wolfhagen@stonybrook.edu \\ ${ }^{5}$ Illinois State Geological Survey, Natural Resources Building, University of Illinois, 615 E. \\ Peabody Ave., Champaign, IL 61820 USA; hongwang@illinois.edu
}




\begin{abstract}
With excavated layers spanning a period from $>49 \mathrm{ka}$ to $~ 36 \mathrm{ka}$, Mochena Borago Rockshelter reveals a complex sequence of Late Pleistocene human occupation punctuated by volcanic events. Fifty-nine radiocarbon ages make Mochena Borago one of the best-dated Late Pleistocene archaeological sites in eastern and northeastern Africa. However, complex site formation processes, dramatic stratigraphic differences between non-contiguous excavation areas, and "outlier" dates that appear in various parts of Mochena Borago's sequence, complicate efforts to develop a secure, detailed chronology for local and regional behavioral changes. This article focuses on contiguous squares within the Block Excavation Area (BXA) trench at the northern end of the shelter. Bayesian modeling of 37 dates from six major lithostratigraphic units within the BXA yields a revised series of age ranges; these differ from the previous age model (derived from weighted means) in subtle but important ways. Perspectives gained through Bayesian analysis stimulate more careful consideration of the complex site formation processes operating at Mochena Borago, the contextual integrity of the site's robust and distinctive flaked stone artifact assemblages (lithics), and potential correlations between lithic changes and environmental events that occur on local, regional, and global scales. As these factors come into focus, Mochena Borago can serve as an important chronological benchmark to better understand human behavior in eastern and northeastern Africa around the time of the second major dispersal of H. sapiens.
\end{abstract}

\title{
Keywords
}

MIS 3; ETHIOPIA; LITHIC TECHNOLOGY; RADIOCARBON; LATE PLEISTOCENE; BAYESIAN MODELING 


\section{Introduction}

During Marine Isotope Stage (MIS) 4 ( 74-57 ka) and MIS 3 ( 57-29 ka) (Stewart \& Jones 2016) Homo sapiens successfully colonized most of the earth's continents. Initial dispersals of H. sapiens from Africa to southwest Asia 125-100 ka took place during the warm, humid conditions of MIS 5. However, further dispersals apparently stalled as the cold and arid conditions of MIS 4 set in (Armitage et al. 2011; Drake et al. 2013; Hovers 2006; Parton et al. 2013; Shea 2008). Genetic and archaeological evidence points to new dispersals of Homo sapiens through and out of Africa during early MIS 3, with humans spreading east and north into southwest Asia and Mediterranean Europe, and south into temperate and tropical Asia and Australia by 50-45 ka (Armitage et al. 2011; Mellars 2006; Mellars et al. 2013; Müller et al. 2011; Soares et al. 2011).

This rapid and unparalleled range expansion of our species has been one of the major questions driving Late Pleistocene archaeological and paleoanthropological research within these regions. Several scholars have hypothesized that toward the end of MIS 5, as conditions deteriorated into the cold, hyper-arid conditions of MIS 4 in many parts of Africa, huntergatherer populations decreased and many groups were forced to migrate into environmental refugia (Brandt et al. 2012; Drake \& Breeze 2016; Stewart \& Jones 2016:8; Stewart \& Stringer 2012).

We propose it was in some of these MIS 4 refugia that various African innovations in technology, communication, mobility, and organization - which had developed during the late Middle Pleistocene in different places, at different times and at different speeds by diverse hunter-gatherer groups (McBrearty \& Brooks 2000) - coalesced to form a novel blend of behavioral patterns. It was this distinct blend of "modern" cultural traits that permitted African hunter-gatherers to meet the challenges of their environmentally circumscribed MIS 4 world. During MIS 3, as African conditions ameliorated albeit with frequent regional and local fluctuations (Jones et al. 2016), these same behaviors allowed human groups to not only move back and forth between Africa and Eurasia (Henn et al. 2012; Soares et al. 2016), but to achieve near-complete coverage of the world by the end of the Pleistocene (Klein 2009).

One of the first steps in testing this hypothesis is to find securely dated Late Pleistocene sequences that span MIS 4 and/or MIS 3 in African refugia. Unfortunately very few such sites are known outside of South Africa (e.g., Haua Fteah in Libya (Douka et al. 2014) and Mumba in Tanzania (Diez-Martin et al. 2009)). Recent excavations at Mochena Borago Rockshelter in SW Ethiopia (Fig. 1) reveal that this site provides a secure, chronometrically dated paleoenvironmental and archaeological sequence for MIS 3, and possibly MIS 4, in a potential Late Pleistocene refugium within eastern Africa (Brandt et al. 2012).

The first published Late Pleistocene radiocarbon chronology for Mochena Borago drew upon 22 charcoal ${ }^{14} \mathrm{C}$ dates from the stratified deposits of the Block Excavation Area (BXA) at the northern end of the rockshelter (Fig. 2). Weighted means of ${ }^{14} \mathrm{C}$ dates from major strata produced a chronology spanning 53-41 ka Cal BP (Brandt et al. 2012; Fisher 2010). In this article, we use Bayesian modeling of 37 charcoal ages to generate a revised chronology for the same Late Pleistocene stratigraphic units of the BXA. Our goal is to use the new Bayesian model to more precisely date Mochena Borago's Late Pleistocene lithostratigraphic sequence, gain a better temporal understanding of the site's complex formation processes, evaluate the contextual integrity and temporal patterning of its distinctive flaked stone artifact assemblages, and explore possible correlations between behavioral changes and environmental events at local, regional, and global scales. Reaching this goal should establish an important chronological benchmark for 
better understanding hunter-gatherer behavior in eastern and northeastern Africa during the time of the second major dispersal of $H$. sapiens through and out of the continent.

\subsection{Current knowledge of chronometrically dated MIS 4 and MIS 3 archaeological sites near dispersal corridors: the Horn and northeastern Africa}

Archaeological sites in the Horn of Africa (Djibouti, Eritrea, Ethiopia, Somalia/Somaliland) and northeastern Africa (Egypt, Sudan) are of particular interest because these regions are argued to be gateways for dispersals out of Africa via Northern and/or Southern Routes (Mellars 2006) (Fig. 1). Unfortunately archaeological research in these regions has revealed very few sites with secure chronological sequences dating to MIS 4. Whether this reflects the difficulties of chronometrically dating sites in the $\sim 70-60 \mathrm{ka}$ range, or represents a true abandonment of vast regions, remains to be shown. Without securely dated, stratified sites from MIS 4, those from early MIS 3 merit especially close study, because they provide evidence for continued occupation of refugia, or reoccupation/colonization of regions by hunter-gatherers employing technologies established during MIS 4 and/or at the beginning of MIS 3. This section provides a succinct summary of all known chronometric ages for sites in the Horn and northeast Africa that were occupied during MIS 4 and/or 3. It also briefly describes lithic assemblages as these artifacts form most if not all of the material remains at these sites.

Near the Southern dispersal route, securely dated evidence for human occupation of the Horn of Africa (Djibouti, Eritrea, Ethiopia, Somalia/Somaliland) during MIS 4-3 is scant and often problematic (Brandt 1986; Brandt et al. 2012; Pleurdeau et al. 2014). Test excavations in 1982 at Midhishi 2 and Gud Gud, two rockshelters in the highlands above the Gulf of Aden in northern Somalia/Somaliland, reveal artifact-bearing strata $>40 \mathrm{ka}$ in age. At Midhishi 2, Middle Stone Age (MSA) assemblages are associated with a single charcoal ${ }^{14} \mathrm{C}$ date of $>40 \mathrm{ka}$, and include chert unifacial and bifacial points made on flakes struck from Levallois centripetal and point cores, including Nubian Type 1 forms (Brandt \& Brook 1984; Brandt \& Gresham 1989; Gresham 1984). The test trench at Gud-Gud yielded a handful of lithics including an end scraper and blades associated with a single ${ }^{14} \mathrm{C}$ date on charcoal of $>40 \mathrm{ka}$. At the painted rockshelter of Laas Geel 7 in northwest Somalia/Somaliland, recent excavations (Gutherz et al. 2014) have revealed lithic assemblages with mixed MSA and LSA (Later Stone Age) characteristics suggestive of J.D. Clark's Hargeisan Industry, but these are dated on the basis of only a single ostrich eggshell (OES) ${ }^{14} \mathrm{C}$ sample to $\sim 42 \mathrm{ka}$ Cal BP.

Porc Epic Cave is situated on the southeastern edge of the Afar Rift in east-central Ethiopia, and overlooks a seasonal river basin near the city of Dire Dawa. Its MSA assemblages remain insecurely dated due to complex stratigraphy and several problematic dates: three contested obsidian hydration ages $(61.2 \pm 0.9,61.6 \pm 1$, and $77.6 \pm 1.6 \mathrm{ka})$, three ${ }^{14} \mathrm{C}$ ages on shell (33.7 ka, $35.6 \mathrm{ka}$, and $>43.2 \mathrm{ka} \mathrm{Cal} \mathrm{BP}$ ), and a date of $\sim 50 \mathrm{ka}$ using low background gamma ray spectrometry on the early Homo sapiens mandible found in 1933 (Assefa 2006; Clark \& Williamson 1984; Leplongeon 2014; Pleurdeau 2005; Rosso et al. 2014). Recent excavations at the nearby cave of Goda Buticha have uncovered lithic assemblages showing a mix of MSA and LSA attributes, and dated via four charcoal ${ }^{14} \mathrm{C}$ determinations to $46-33 \mathrm{ka}$ Cal BP (Leplongeon 2014; Pleurdeau 2014). Recent fieldwork in the central part of the Main Ethiopian Rift has revealed a series of open-air and shelter sites containing blade-based LSA assemblages. As yet only one of these sites (DW1) dates to MIS 3 on the basis of a single ${ }^{14} \mathrm{C}$ charcoal age of $\sim 33 \mathrm{ka}$ Cal BP (Ménard et al. 2014). 
Along the proposed Northern dispersal route in northeast Africa, only a handful of sites have chronometric ages, and even fewer are securely dated within the MIS 4-3 timespan. At Sodmein Cave in Egypt's Red Sea Hills, a deep stratified sequence spanning $>100,000$ years has four strata potentially dating to this interval (Moeyersons et al. 2002; Schmidt et al. 2015; Van Peer et al. 1996; Van Peer \& Vermeersch 2000). The earliest is Layer G (MP4), dated by two charcoal ${ }^{14} \mathrm{C}$ samples to $\geq 30 \mathrm{ka}$ and $\geq 45 \mathrm{ka}$. An OSL date of $89 \pm 9 \mathrm{ka}$ and a TL date of $87 \pm 9 \mathrm{ka}$ from a single sample within Stratum J, two layers deeper in Sodmein's sequence and below a major stratigraphic break, serve as a terminus post quem for Layer G. Classic Levallois and Nubian 1 lithic assemblages from these sites are assigned to the Late Nubian Complex of the 'Middle Paleolithic' (MP) (Marks 1968) now referred to as MSA (Van Peer 2016; Wurz \& Van Peer 2012).

Sodmein Stratum F/G (MP3), which has a single ${ }^{14} \mathrm{C}$ age on charcoal (K. Kindermann pers. comm) of $>45 \mathrm{ka}$, is also associated with MSA assemblages that include classic Levallois and Nubian Type 1 Levallois cores and debitage, as well as a few truncated-facetted pieces suggestive of connections to the Late Nubian Complex of the Nile Valley. Higher in the sequence, Layer F (MP2) has MSA assemblages dominated by a Levallois reduction strategy that includes a possible tanged Levallois flake. Although Van Peer et al. (1996) report two ${ }^{14} \mathrm{C}$ dates of $\sim 29.95 \mathrm{ka}$ and $\geq 30 \mathrm{ka}$ (material and calibration unspecified) from this layer, Moeyersons et al. (2002:842) do not include these dates in their chronology. Layer E (MP1, undated but sandwiched between the dated strata F and D) has low densities of artifacts that include burins and two Emirah points. Finally, Layer D, which bears 'Upper Paleolithic' lithic assemblages emphasizing blades and single-platform cores, has only a single ${ }^{14} \mathrm{C}$ age of $\sim 25.2 \pm 5 \mathrm{ka}$ (material and calibration unspecified) from an associated hearth (Van Peer et al. 1996).

Taramsa 1 is a late Pleistocene multi-activity chert quarry and burial site on a hill overlooking the west bank of the Nile in Upper Egypt (Fig. 1). In 1994 researchers discovered the poorly preserved, fragmentary remains of an anatomically modern child that had evidently been placed alongside the quarry extraction pits. One OSL date of $76.2 \pm 4 \mathrm{ka}$ from sand near the skull and another at $68.6 \pm 8 \mathrm{ka}$ from sediments overlying the burial represents the most likely age of the child, as well as associated late Nubian Complex lithics. Van Peer et al. (2010) argue that the youngest series of quarrying activities at the site are associated with the Taramsan, a transitional industry characterized by a distinct blade production strategy that developed out of a Levallois reduction system. The age of the Taramsan is problematic, but six OSL dates suggest $61.9 \pm 7$ to $56.9 \pm 7 \mathrm{ka}$ and possibly as late as $\sim 40 \pm 4 \mathrm{ka}$.

The Lower Nile Valley Complex (Van Peer \& Vermeersch 2000) is a distinct technological tradition characterized by classic Levallois assemblages thought to overlap temporally with the Late Nubian Complex referred to above. Chronometrically dated sites that best represent the Lower Nile Valley Complex include Nazlet Sahafa 2 and Nazlet Khater 4 (Fig. 1). Nazlet Sahafa 2, known for its distinctive Sahafa reduction system, is OSL dated by a single sample to 59.8 $\pm 6.6 \mathrm{ka}$ (Stokes \& Bailey 2002; Van Peer 1991). Among several quarry sites on Nile terrace remnants overlooking the western Nile floodplain (Vermeersch 2002), Nazlet Khatar 4 is a localized set of ditches, vertical shafts, and galleries for extraction of cherts found in Nile gravel deposits. Nine ${ }^{14} \mathrm{C}$ dates on charcoal from intact hearths, dumps in extraction shafts or ditches, and charcoal scatters range from $\sim 30.4 \pm 2.3 \mathrm{ka}$ to $35.1 \pm 1.1 \mathrm{ka}$ (calibration unspecified)

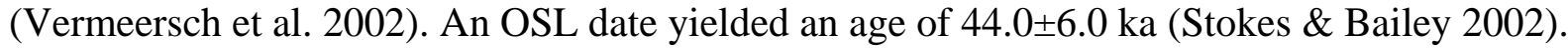

The Khormusan industry is found at several sites situated overlooking the Nile near today's Egypt/Sudan border. There is little consensus on the timing of this industry, as 
chronometric dating of Khormusan sites has been problematic. Four charcoal radiocarbon ages obtained in the 1960s and 1970s yielded ages of $20.9 \pm 0.28 \mathrm{ka}$ (now rejected due to incomplete pretreatment), $>36 \mathrm{ka},>36.7 \mathrm{ka}$ and $>41.4 \mathrm{ka}$; the $21 \mathrm{ka}$ date is considered to be too young due to incomplete radiocarbon pretreatment, while the other three are minimal ages for the Khormusan that also reflect radiocarbon 'limits' for laboratories of that era (Wendorf et al. 1979). An

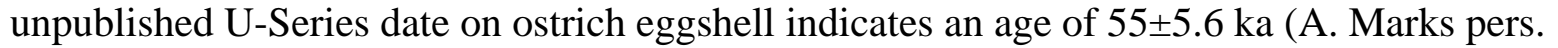
comm. 1992, cited by Sellet 1995). However, Goder-Goldberger (2013) argues that OSL dates from geological localities in and around the Nile Valley suggest Khormusan sites may range from $\sim 85-65$ ka in age. Van Peer \& Vermeersch (2000) included the Khormusan in the Nubian Complex, but Goder-Goldberger (2013) emphasizes affinities to eastern African MSA traditions, particularly between Khormusan Site 1017 and Omo Kibish sites BNS and KHS in southernmost Ethiopia, thereby implying that at least some of the Khormusan sites are of MIS 5 age.

This brief survey reveals the paucity of chronometrically dated evidence for human behavior during MIS 4 and MIS 3. Sites from the Horn have only $\sim 11{ }^{14} \mathrm{C}$ ages and three contested obsidian hydration dates, and sites from Sudan and Egypt have only $\sim 18{ }^{14} \mathrm{C}$ ages, 12 OSL dates, and an unspecified number of U-series dates. Together, these regions span an area almost the size of the continental United States! Due to the current $50 \mathrm{ka}$ "limit" on radiocarbon dating and calibration, as well as the inability to use OSL dating in volcano-derived sediments (Gliganic 2011), it remains difficult to find sites with securely dated archaeological sequences from late MIS 4-early MIS 3 that can be used to gauge diachronic and synchronic changes in material culture during this critical period in the behavioral evolution of Homo sapiens. Mochena Borago Rockshelter in the highlands of southwest Ethiopia offers the opportunity to anchor one such sequence.

\section{Mochena Borago Rockshelter}

Positioned on the southwest side of Mt. Damota (Fig. 1), a dormant trachytic volcano overlooking the Main Ethiopian Rift northwest of Lake Abaya, Mochena Borago lies at the intersection of three major environmental systems within the Horn. To the west of Mt. Damota, the southwest Ethiopian highlands (>2700-500 m asl) contain habitats of Afromontane (highland), Transitional (midland), and Guinea-Congolian (lowland) forests cut by major river valleys. To the east and south, the Ethiopian Rift contains lakes and open vegetation in a dry, hot environment flanked by escarpments. To the northeast, the Afar Depression is currently a vast lowland desert with scant rainfall and sparse vegetation. Hunter-gatherers would have had to be comfortable in this hostile environment in order to reach the Bab el Mandeb. The inhabitants of Mochena Borago would have been aware of most if not all these environments, and may have made periodic use of any/all of them.

\subsection{Context and history of research at Mochena Borago}

Located in a ravine running down Damota's southwest flanks, Mochena Borago Rockshelter furnishes a large, open living space, with an opening almost $70 \mathrm{~m}$ wide, a height of $12 \mathrm{~m}$, and a maximum distance of $20 \mathrm{~m}$ from dripline to rear wall. Its flat floor consists mainly of fine silt/clay surface material, punctuated by a few massive volcanic boulders in different areas. Today, the floor surface is dry, except where spray from the ravine's waterfall dampens sediment near the center of the dripline. During heavy rains, minor dripping from the roof of the shelter moistens the ground near excavation unit F9. However, local Wolaita remember significant water flow into the shelter from the northwestern side in recent times. 
R. Joussaume led initial investigations at Mochena Borago in 1995, and in 1998 excavated a $1 \times 1.5 \mathrm{~m}$ unit in the northern part of the shelter that revealed nearly $2 \mathrm{~m}$ of stratified archaeological deposits, including almost a meter of Late Pleistocene sediments (Gutherz, 2000). In 2000-2002 X. Gutherz, seeking evidence for early food production, directed excavations of Holocene deposits across $>20 \mathrm{~m}^{2}$ of the shelter's northern area, now known as the "Block Excavation Area" (BXA), as well as a test unit (TU2) a few meters to the east (Gutherz et al. 2002) (Fig. 2). Gutherz et al. later expanded excavations of Holocene deposits to the south.

In 2006 S. Brandt and E. Hildebrand established the Southwest Ethiopia Archaeological Project (SWEAP), and with E. Fisher excavated Mochena Borago's Late Pleistocene deposits from 2006 to 2008 with the aim of testing the hypothesis that southwest Ethiopia's highlands formed a refugium for human populations coping with the cold arid conditions of MIS 2, including the Last Glacial Maximum (LGM) (Brandt et al. 2012; Fisher 2010). Excavations probed deeper within BXA units G10, G9, H9, and I10), as well as units farther south (e.g., M1315) (Fig. 2). SWEAP also opened a new series of excavation units aligned to cardinal directions in the eastern side of Mochena Borago, running west from N42E38. Nineteen charcoal dates yielded ages between 48 and $26{ }^{14} \mathrm{C}$ ka. With bedrock not yet reached, and no Late Pleistocene deposits postdating the onset of MIS 2, it became clear that although Mochena Borago might not shed light on human behavior during the LGM, it could offer important data for much of MIS 3 and perhaps even MIS 4.

From 2009-2014, research continued under the direction of S. Brandt (SWEAP) and R. Vogelsang (CRC 806, http://www.sfb806.uni-koeln.de) with the goal of documenting behavioral changes relevant to human dispersals out of Africa (Brandt et al. 2012). They continued to probe lower archaeological layers of BXA, including the lowest levels of units G9 and H9 just above a thick, impenetrable volcanic layer that forms the base of the BXA sequence (Fig. 3). Eighteen further AMS measurements focused on these occupation layers. Seeking evidence for MIS 4 occupation, the team also opened new trenches outside the BXA (Fig. 2) and found other complex stratigraphic sequences. Continued SWEAP excavations in 2015-2016 have opened and expanded new trenches in the eastern part of the shelter. Analyses relating these sequences to the BXA are ongoing, along with micromorphology sampling and geomorphological investigations of site formation processes. This paper only presents and analyzes radiocarbon dates from the Late Pleistocene BXA sequence.

\subsection{Depositional history of Block Excavation Area (BXA)}

Excavations in different parts of the rockshelter have revealed diverse, highly localized lithostratigraphic sequences. Because Bayesian analysis uses known stratigraphic relations to constrain phase models, it is best applied to contiguous deposits, such as BXA's major stratigraphic groups from PKT, the impenetrable basal volcanic layer, to BWT, an early Holocene tephra that caps the BXA Late Pleistocene sequence (Fig. 3). This descriptive overview of BXA's main strata draws upon previous stratigraphic information and depositional interpretations prior to 2012 (Brandt et al. 2012; Fisher 2010), as well as new data and observations obtained during the 2012-2015 field seasons (Meyer et al. n.d.).

The BXA lithostratigraphic sequence was formed by single to complex combinations of distinct processes. Geogenic processes include volcanic eruptions; stream incising, ponding and other fluvial activities; shelter roof collapse or fall; wall collapse and erosion; chemical dissolution; and colluvial activities. Anthropogenic processes consist of human activities, such as the knapping, curating and discarding of flaked, ground and smoothed stone and ochre artifacts; the creation of combustion features and diffuse to dense concentrations of charcoal; and the 
discard of food remains exemplified by animal bones in various, but usually poor states of preservation (Karkanas et al. 2015; Meyer et al. n.d.). Sediments formed through either or both processes may undergo subsequent bioturbation by plants (root growth), and by digging, tunneling and displacement by insects and other animals.

BXA's seven main strata (Fig. 3) are described from earliest (PKT, $>49$ ka) to latest (RGroup, ending 39-36 ka). Dates for each major stratigraphic unit will be presented in Section 4.5 (Table 4), where readers can compare previously published weighted means (Brandt et al. 2012) with new age ranges derived from the Bayesian modeling undertaken in Section 4.

The volcanic layer PKT is the deepest and oldest stratum in the BXA sequence, and the only BXA stratum that has yielded no datable material. Exclusively geogenic in origin (Meyer et al. n.d.), it is an extremely hard lahar (mud flow) that is especially difficult to penetrate in the small confines of $1 \mathrm{~m}^{2}$ excavation units. At least 1 meter thick and archaeologically sterile, PKT is effectively the "bedrock" for the BXA as we have been unable to reach any underlying deposits. However, it is not universal throughout the rockshelter as it appears to be missing in some of the other non-contiguous excavation units south and east of BXA.

The $\sim 40 \mathrm{~cm}$ thick T-Group sediments (Fig. 3) unconformably overlie PKT and were formed by a mix of geogenic and anthropogenic processes, with some evidence for bioturbation even in recent times (e.g. tunneling by land crabs). They are divided into two sub-groups: 'Lower T-Group' and 'Upper T-Group' (Brandt et al. 2012; Fisher 2010). Lower T-Group deposits have gravels, likely derived from the rockshelter's roof, within a dark, often saturated matrix indicative of high organic content. The heavily weathered, reworked clay coatings and calcite fillings suggest the periodic presence of small to large pools of standing water and/or slow moving streams during the more humid phases of early MIS 3. Upper T-Group sediments are redder and less weathered, suggesting stronger aeolian inputs and possibly drier conditions. However, compacted aggregates of fine, iron-rich illuvial clay bands also suggest periods of increased water flow. Both Lower and Upper T-Group facies provide clear evidence for human activities, in the form of abundant flaked stone artifacts (lithics) and charcoal, as well as ochre, hematite, poorly preserved comminuted animal bone, and one human incisor.

The geogenic YBT tephra consists of $20 \mathrm{~cm}$ of yellow-brown volcanic ash that overlies T-Group. Currently we are uncertain if this contact is conformable or unconformable. The almost complete dearth of artifacts suggests a major interruption in human use of the shelter. In some areas, thin-bedded laminae suggest the tephra accumulated in small pools or slow-moving streams.

Formed by geogenic and anthropogenic processes, the $\sim 30 \mathrm{~cm}$ thick S-Group sediments overly YBT with a major unconformity (Fig. 3). S-Group deposits are characterized by a series of silty clays and dark brown silts with little gravel, and encompass large numbers of charcoal and lithics as well as ground/smoothed stone, worked pigments and poorly preserved bone indicative of renewed human activities. Some S-Group deposits show strong evidence for fluvial activity: a paleofluvial channel runs through G10, and many lithics show significant "damage" (Parow-Souchon et al. n.d.) that may be partly due to post-discard transport. Elsewhere, however, fluvial effects are not obvious, as sediment matrix is dominated by small particles (clays, silts).

YBS is a weakly sorted, consolidated yellow brown silt that accumulated through colluvial action as a volcaniclastic mud flow with abundant ash and gravel (Brandt et al. 2012; Meyer et al. n.d.). It overlies the S-Group without any visible unconformity. At least $12 \mathrm{~cm}$ thick, it represents a second significant hiatus in human occupation as YBS has only a few lithics and 
pieces of charcoal, most of which appear to be in secondary context and emanating from overlying deposits.

Overlying YBS with only minor visible evidence for an unconformity, R-Group deposits are geogenic and anthropogenic in origin. About $30 \mathrm{~cm}$ thick on average, R-Group's matrix is clay/silt. Round to subrounded gravels are especially prevalent in lower R-Group deposits and probably derive from roof-fall. The matrix has distinctive dark brown to reddish hues suggesting iron oxidation, and the porous microstructure in upper levels of R-Group has voids filled by oriented and laminated reddish orange clay particles (Fisher 2010); micromorphology observations by P. Goldberg (pers. comm.) suggest standing water in parts of the BXA (Brandt et al. 2012). Abundant lithics and other materials indicate renewed human use of the rockshelter. More than two-thirds of the lithics show significant abrasion, ranging from angular to rounded, but around a third are fresh (Bermensolo 2013). Together, R-Group deposits and lithics suggest discontinuous sedimentation in which artifacts were sometimes exposed on the surface for variable periods of time before they were subsequently covered in depositional events or displaced by erosion.

The BXA's Late Pleistocene sequence is capped by BWT, a dense, homogeneous white tephra derived from an early Holocene volcanic eruption (Fig. 3). The tephra entered Mochena Borago via aeolian processes, settled in situ, and underwent minor rearrangement via fluvial processes in some areas, as the base of BWT is weathered and iron-stained. The R-Group/BWT interface shows only subtle signs of unconformity in the form of small concavities in R-Group's top surface. However, the long temporal gap (>20,000 years) between the two adjacent strata suggests major erosional processes must have come into play prior to the deposition of BWT.

\subsection{Lithic technological changes in the MIS 3 levels of Block Excavation Area}

The major artifact-bearing stratigraphic groups within BXA's late Pleistocene deposits have yielded >40,000 flaked stone (lithic) artifacts. Ground/smoothed stone and ochre artifacts also appear throughout the sequence. For now we have refrained from establishing any kind of culture-stratigraphic framework, and instead for analytical purposes have used the Lower and Upper T-Groups, S-Group and the R-Group natural lithostratigraphic units to place the assemblages within a chronological sequence (Table 1). Brandt et al. (2012) presented preliminary data from T-Group and S-Group assemblages; here we incorporate recent detailed analyses of R-Group lithics (Bermensolo 2013, Parow-Souchon 2013; Parow-Souchon et al. n.d.) and further examination of T-Group artifacts into a summary of technological trends within the BXA.

Perhaps the most distinguishing aspect of Mochena Borago's lithics is their diminutive size. All artifacts, regardless of age or type, are on average $<30 \mathrm{~mm}$ in length (Brandt et al. 2012; Ménard 2015). This contrasts with most other sites in eastern Africa dating to the same general time period where artifacts tend to be significantly longer. Possible explanations for the small size of Mochena Borago's lithics include restricted access to raw materials, functional needs related to tools including weaponry (e.g. the bow and arrow), a "waste not want not" attitude toward core reduction, and "cultural tradition". We continue to explore these and other explanations through various avenues of research, including residue and use wear studies (V. Rots pers. comm.).

The overwhelming choice for lithic raw material was obsidian, forming at least $94 \%$ of all lithic assemblages (Table 1). Portable XRF analyses point to the eroded hills of Baantu on the western edge of the Rift $\sim 20 \mathrm{~km}$ southeast of Mochena Borago as the source for most obsidian 
recovered at the rockshelter (Warren 2010). This obsidian source is still used today by local craftsmen who make scrapers for working hides, a practice still in play among some ethnic groups in southwest Ethiopia (Brandt \& Weedman 2002). Stratified random surveys of Baantu identified multiple localities where large blocks quarried from flows, or weathered nodules collected on the surface were available in practically any size and shape. Surface scatters and the test excavation of an in-situ artifact concentration leave no doubt that obsidian knappers from the late Acheulian onwards worked at Baantu to reduce cores of varying types and sizes. This would make it difficult to argue that raw material constraints represent a viable explanation for small lithic size at Mochena Borago. A small percentage of Mochena Borago obsidian comes from source(s) other than Baantu, whose location(s) have yet to be identified.

One of the most puzzling aspects of the Mochena Borago lithic assemblages is the presence of abraded lithics in association with unabraded 'fresh' lithics. Rare in T-Group strata, they become common in S-Group and R-Group assemblages. We are examining various explanations for these "damaged" lithics, including chemical and fluvial processes as well as long periods of exposure on the surface of the shelter (Bermensolo 2013; Parow-Souchon 2013; Parow-Souchon et al. n.d.).

Mochena Borago knappers were clearly aware of a wide range of core reduction strategies, but chose to concentrate upon only one. The predominant core reduction strategy involves the production of elongated flakes and occasional blades from minimally prepared, tabular-shaped single, double, or multiplatform ("Tabular SDM") cores whose size and shape change little over time. Levallois reduction methods are surprisingly diverse given that they represent only $8-18 \%$ of all cores from any stratigraphic group. They include small unidirectional and recurrent centripetal Levallois flake cores, classic unidirectional point cores, and remarkably small, thin Nubian Type 1 and 2 point cores. Other persistent but rare reduction strategies designed to produce flakes and irregular blades/bladelets include small discoidal and angular cores. Bipolar cores are rare in T-Group strata, but frequencies increase dramatically in S-Group and R-Group sediments. Small but classic prismatic/pyramidal and single- to multi-platform blade cores and their parallel-sided blades/bladelet products occur throughout the sequence, but in very small numbers (Parow-Souchon et al. n.d.).

As is the case with most eastern African Late Pleistocene assemblages, the importance of shaping (façonnage) is clearly reflected in the unifacial, parti-bifacial and bifacial points from Mochena Borago. In some instances, complex scar patterns attest to the considerable skill, time and effort knappers put in to the making of bifacial points, especially foliate and triangularshaped ones. The points derive largely from small elongated flakes struck from Tabular SDM cores, although a few appear to be made from blades. Unretouched or minimally retouched classic Levallois and Nubian points are also present, but rare. One of the few clear temporal changes in the Mochena Borago lithic sequence is diminishing frequency of points over time. Lower T-Group strata have the highest percentage of points throughout the sequence, and also represent the highest frequency of shaped tools in that group (62\%). Points drop to $42 \%$ of all shaped tools in Upper T-Group, and further still in S- and R-Groups.

Small backed pieces represent the other major temporal change in shaped tools. They are rare in the Lower T-Group, become more prevalent in Upper T-Group, and continue to rise in frequency through the S-Group and R-Group assemblages, reaching the second highest percentage of any shaped tool. All backed pieces but one (a crescent from Upper T-Group) are non-geometric in form. They are heterogeneous, and include curved, straight and irregularly backed examples. Also present are backed flakes and blades/bladelets, some with use-wear on 
the opposite edge, others with the backed edge and retouch on opposite edge forming an awl-like tip, and others with proximal or distal truncations. Other shaped tools include end and side scrapers, which consistently form $\sim 20-40 \%$ of shaped tools from each Group, as well as a few drills, burins and notches.

\subsection{Approaches to dating the Mochena Borago sequence}

Our previous age model of Mochena Borago's Late Pleistocene sequence relied on weighted means of 22 dates calibrated by CalPal 2007 (Weninger \& Jöris 2008) to generate probable age ranges for major stratigraphic groups (Brandt et al. 2012). The 2012 paper calculated weighted means via a Central Age Model (CAM), which has commonly been used for optically-stimulated luminescence (OSL) dating in order to aggregate the log-paleodose results of multiple quartz grains in a sample, particularly when those results are over-dispersed from a common mean (Galbraith et al. 1999, 2005). Dates were weighted by the inverse of their standard deviation, which downplayed the contributions from dates with larger errors. As we built our initial age model (Brandt et al. 2012), weighted means struck us as a better way to generate age ranges for larger stratigraphic units, rather than simply averaging dates within a stratum. However, reconsideration of the applicability of the Central Age Model to radiocarbon dating has led us to re-evaluate our approach to dating BXA contexts.

Our initial premise that charcoal dates from the stratigraphic units at BXA can be considered a "population of samples that are assumed to have similar external influences" (Brandt et al. 2012:44) no longer appears secure for cultural layers within the BXA. Each major stratigraphic group that is rich in artifacts (e.g., Upper T-Group) encompasses many depositional events - during which datable material entered the stratigraphic sequence multiple times from a variety of sources - rather than a single event whose timing we want to estimate (see Section 2.2). Thus, the charcoal samples found in Mochena Borago's Pleistocene cultural layers, and the many independent events they record, are poor analogs to multiple quartz grains within an OSL sample.

If multiple radiocarbon samples can be taken from a relatively discrete context (e.g., a hearth) that reflects a short-term single event analogous to the dosing of quartz grains in OSL, then the Central Age Model might be appropriate to estimate a midpoint age of its use. The YBT and YBS tephra represent discrete events. However, because the charcoal found in these layers may not be directly associated with the volcanic events themselves (see Section 2.2), the Central Age Model is again inappropriate.

Mean dates for composite stratigraphic groups are therefore less useful for understanding depositional processes than an estimate of the start and end dates for each major stratigraphic group, which is possible using Bayesian inference (Bayliss 2009). The Bayesian analysis employed here models major stratigraphic units in a sequence. Each individual unit is modeled as a uniform phase, meaning that we place no expected relationship on individual dates within each phase (Bronk Ramsey 2009; see Section 4 for more details).

Switching to a Bayesian framework resolves four other disadvantages associated with use of weighted means. First, weighted means tend to be more heavily influenced by younger samples because older radiocarbon dates generally have larger standard deviations than younger dates; this could skew the BXA chronology to be generally younger, and even allow intrusive dates from a later time period to have an exaggerated influence on the sequence if their standard deviations are small. Bayesian analysis does not share this bias. Second, we saw that several dates were outliers with different possible causes, but lacked a mathematically rigorous way to 
assess outliers and prevent them from exercising undue influence on the weighted mean for a group. Methods for automatically identifying and rectifying outlier dates can be included in Bayesian models (Bronk Ramsey 2009a,b). Third, the procedure of constructing weighted means did not make use of the fact that contiguous stratigraphy can help constrain date models (e.g., Lower T-Group deposits must be older than Upper T deposits). Bayesian modeling uses stratigraphic data to constrain the uncertainty of individual radiocarbon dates. Finally, because each weighted mean calculation generated an age range that was represented as a normal

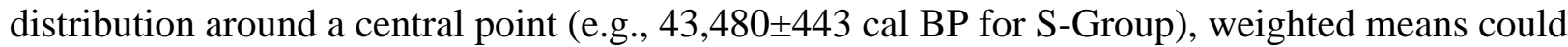
not generate probability distributions that were non-normal, bimodal, or multimodal. Bayesian calibration directly draws from the IntCal 13 calibration curve, allowing date estimates to be expressed as probability ranges with multiple peaks (Buck et al. 1996:213).

\section{Dating methods and results}

Due to chronological proximity to the "dating barrier" ( $40-50 \mathrm{ka})$, the MIS 3 deposits in Mochena Borago have presented challenges and opportunities for geochronological research. In 2007, we sought to compare results from multiple dating methods: radiocarbon dating of charcoal, OSL of rockshelter deposits, application of ${ }^{40} \mathrm{Ar} /{ }^{39} \mathrm{Ar}$ to tephra layers, and ESR of a tooth. Unfortunately, due to various properties of Mochena Borago and its sediments, only radiocarbon proved practicable (Brandt et al. 2012).

\subsection{Radiocarbon sample collection, selection and curation}

Following our first field season in 2006, we submitted six charcoal samples to the Illinois State Geological Survey (ISGS). To ensure sufficient charcoal for conventional ${ }^{14} \mathrm{C}$ dating, we combined charcoal finds from a single excavation unit and (maximum $5 \mathrm{~cm}$ ) level into an aggregate dating sample. Thus each 2006 sample consisted either of all sieved charcoal pieces from a single square/level, or multiple plotted charcoal pieces from a single square/level. Collections included both sieved and plotted finds. All these samples all generated highly problematic results, likely due to mixing and/or contamination during sample collection, and are not presented here.

Beginning in 2007 and in all subsequent field seasons, we piece-plotted all artifacts, bone, and charcoal fragments $>2 \mathrm{~mm}$ in size using Trimble TS-305 and Leica TS02 Total Stations. From 2007 on, all charcoal samples were submitted for AMS dating. Each sample represented an individual occurrence of charcoal within a $1 \mathrm{~cm}^{3}$ area. Most samples were much smaller than $1 \mathrm{~cm}^{3}$ - more typically $2-5 \mathrm{~mm}$ in any dimension. In most cases charcoal was tightly gripped by surrounding matrix, usually a compacted silt/clay. These conditions seemed ideal for preventing vertical or horizontal slippage, but also caused fragmentation during recovery. Small size and breakage together impeded identification of the type of carbonized plant tissue (e.g., wood, stem, leaf, or fruit). In some cases, the charred material appeared to be a structurally intact chunk of carbonized plant material, but in others, it was not clear whether tissues were still in their original form.

To avoid contamination during collection, and due to the fragile state of the samples, we did not attempt to separate charcoal from its surrounding matrix. All radiocarbon samples were collected and handled using metal spoons or tweezers, and placed directly into a plastic bag. (Aluminum foil was not used because it contains lubrication oil that may contaminate samples.) All dates presented here reflect this protocol: they are from individually piece-plotted, untouched charcoal samples. Twenty-four samples were submitted to the Illinois State Geological Survey's 
Radiocarbon Dating Laboratory (ISGS) between 2007 and 2014, and thirteen were submitted to the University of Cologne Centre for Accelerator Mass Spectrometry (UCCAMS) between 2012 and 2014.

\subsection{Sample treatment and processing}

We considered the relative merits of Acid-Base-Acid (ABA), Acid-Base-Oxidation (ABOx) and high temperature pyrolysis pretreatments. Various concerns shaped our choice of pretreatment methods. ABA pretreatments have a long history of use and are well known (Brock et al. 2010). ABOx pretreatments use a solution of potassium dichromate and sulphuric acid $\left(\mathrm{K}_{2} \mathrm{Cr}_{2} \mathrm{O}_{7}+\mathrm{H}_{2} \mathrm{SO}_{4}\right)$ to further oxidize acid-base pretreated charcoal samples (Bird et al., 1999). Some studies have shown that ABOx can improve age determination of charcoal samples up to 55 ka by more thorough removal of younger carbon contaminants (Bird et al. 1999; Higham et al. 2009; Santos et al. 2003; Turney et al. 2001). In split-sample comparison tests of ABOx vs. $\mathrm{ABA}$, the ABOx method has indeed generated older dates than the ABA method in some cases; however, in other cases ABOx yielded similar or younger ages than ABA (Haesaerts et al. 2013; Rebollo et al. 2011).

ABOx pretreatment also raises two concerns. First, use of $\mathrm{H}_{2} \mathrm{SO}_{4}$ in the wet oxidation stage releases volatile sulphur compounds that hinder the graphitization step just prior to AMS ${ }^{14} \mathrm{C}$ measurements, potentially decreasing sample size and thus increasing dating uncertainties (Santos et al. 2003). Second, the solution of potassium dichromate and sulphuric acid is a strong oxidation agent that severely degrades charcoal fragments, and in some cases risks loss of the entire sample (Knicker et al. 2007).

Pyrolysis is a third pretreatment option, which can be deployed after samples have undergone ABA or ABOx reactions. Pyrolysis removes hydrocarbon, polycyclic carbon, and other absorbed humic compounds by purging and then oxidizing released volatile compounds of the organic sample at $800^{\circ} \mathrm{C}$ using $\mathrm{Ar}$ and $\mathrm{O}_{2}$ gas, which converts organics into graphitic-like carbon black for AMS ${ }^{14} \mathrm{C}$ dating (Wang et al. 2010). The graphitic-like carbon black is the biomarker of carbon-carbon bonded aromatic molecules that are most resistant to weathering and biodegradation (Wang et al., 2003), and could be the ideal organic compound fraction for dating degraded charcoal fragments. However, pyrolysis requires large samples.

On arrival in the ISGS lab, Mochena Borago samples were dried and examined in preparation for pretreatment. At this stage, some samples appeared loose and crumbly while others retained some structural coherence. It was impossible to separate charcoal powders from the fine-grained sediments that accompanied them, either before or during pretreatment. Because samples were so small and fragmentary, there was not enough material to conduct high-dosed acid pretreatments such as ABOx. Therefore, the only suitable initial pretreatment was the standard acid-base-acid (ABA) method. By the end of ABA pretreatment, samples consisted of disseminated charcoal mixed with fine grained dark sediments, and had insufficient carbon for pyrolysis.

ISGS ABA pretreatment involves boiling for $1 \mathrm{~h}$ in $2 \mathrm{M} \mathrm{HCl}$ and rinsing to neutrality with $\mathrm{DH}_{2} \mathrm{O}$; soaking in cool $0.125 \mathrm{M} \mathrm{NaOH}$ for $1 \mathrm{~h}$ and rinsing to neutrality with $\mathrm{DH}_{2} \mathrm{O}$; soaking in $2 \mathrm{M} \mathrm{HCl}$ for 30 min and rinsing to $\mathrm{pH} 6$ with $\mathrm{DH}_{2} \mathrm{O}$, and finally overnight drying in an $80^{\circ} \mathrm{C}$ oven. ISGS ${ }^{14} \mathrm{C}$-free wood background and wood working standard samples - including IAEA C5 (Two Creek forest wood), FIRI-D (Fifth International Radiocarbon Inter-comparison D wood), and ISGS Reiley AC (about 3 half-life wood) samples underwent the same pre-treatment (Wang et al. 2003). 
ISGS charcoal samples, and wood background and working standards, are sealed with $\mathrm{Cu}$ granules in preheated quartz tubes for combustion $\left(2 \mathrm{~h}\right.$ at $\left.800^{\circ} \mathrm{C}\right)$. Then tubes are cooled from $800^{\circ} \mathrm{C}$ to $600^{\circ} \mathrm{C}$ for $6 \mathrm{~h}$ so $\mathrm{Cu}$ reduces the nitrogen oxides to nitrogen gas. Purified $\mathrm{CO}_{2}$ is submitted to the University of California-Irvine's Keck Carbon Cycle AMS Laboratory for AMS

${ }^{14} \mathrm{C}$ analysis using the hydrogen-iron reduction method. All results undergo isotopic fractionation correction following Stuiver \& Polach (1977), with AMS spectrometer measurement of $\delta^{13} \mathrm{C}$ values on prepared graphite.

AMS results are examined to ensure that all ISGS working standards are within target values with 1-2 standard deviations. Background blanks are older than $53,300{ }^{14} \mathrm{C}$ bp with $\mathrm{F}^{14} \mathrm{C}$ of 0.0013 (>57,000 Cal BP; Hughen et al. 2006) against the internal background of the AMS facility. This suggests that charcoal samples with ${ }^{14} \mathrm{C}$ ages above $40 \mathrm{ka}$ (e.g. $41,580{ }^{14} \mathrm{C}$ bp with $\mathrm{F}^{14} \mathrm{C}$ of 0.0057 and $48,850{ }^{14} \mathrm{C}$ bp with $\mathrm{F}^{14} \mathrm{C}$ of 0.0023 ) are true finite ages.

ICCAMS lab procedures are described in detail by Rethemeyer et al. (2013), and briefly reviewed here. Carbon extraction from charcoal proceeds via standard ABA extraction to remove inorganic carbon and humic substances (Rethemeyer et al. 2013 refer to this as 'acid-alkali-acid (AAA)' but it involves the same reagents used by ISGS above, albeit with different concentrations and reaction times). After acid extraction of the sample (1\% $\mathrm{HCl}, \sim 10 \mathrm{~h} @ \mathrm{SRC})$, the residue is washed repeatedly with Milli-Q water (Millipore, USA). The alkali extraction (1\% $\mathrm{NaOH}, 4 \mathrm{~h}, 60^{\circ} \mathrm{C}$ ) yields a non-soluble residue (humin) and an alkali-soluble fraction. From the latter, humic acids are precipitated via acidification $(37 \% \mathrm{HCl}$ to $\mathrm{pH}<1)$; the precipitate is then rinsed with Milli-Q water to a $\mathrm{pH}$ of about 2. The humin fraction is washed repeatedly (Milli-Q water). Re-treatment ( $1 \% \mathrm{HCl}$ ca. $10 \mathrm{~h} @ \mathrm{SRC})$ removes atmospheric $\mathrm{CO}_{2}$ that might have been introduced during the alkali extraction, and followed by a final rinse with Milli-Q water to $\mathrm{pH}>$ 4 (Rethemeyer et al. 2013).

Very small samples follow a modified carbon extraction procedure from that listed above, with reduced first acid extraction time $-1 \mathrm{~h} @ \mathrm{SRC}-$ and no alkali extraction (Rethemeyer et al. 2013).

Sample combustion and graphitization uses advanced automatic graphitization equipment linked to an Elemantar VarioMicroCube elemental analyzer with a combustion tube ( $\mathrm{PbCrO} 4$ and copper oxide) and a reduction tube (copper and silver wool). $\mathrm{CO}_{2}$ from combustion enters a reactor of the AGE where the catalyst $(\mathrm{H}$ over $\mathrm{Fe}$ ) converts it to graphite. Graphitized samples are stored in glass tubes filled with Ar to prevent contamination, and finally pressed into AMS target holders. To assure the quality of the sample handling and graphitization procedures UCCAMS measures organic and bone standard materials selected from the Fifth Radiocarbon Intercomparison exercise (Rethemeyer et al. 2013).

\subsection{Lab results and unmodeled calibration}

Supplementary Data Table A presents lab results in uncalibrated radiocarbon years, along with unmodeled individual calibrations via CalPal (the system we used in 2012) and IntCal (the system we use today). In this and all other tables and figures, dates are placed in their stratigraphic groups and then ordered according to the elevation of each sample.

\section{Bayesian modeling methods and results}

Applying Bayesian modeling to radiocarbon calibration has enhanced the precision of archaeological description and interpretation across the entire range of radiocarbon dating (Bayliss et al. 2015; Benazzi, 2011; Douka et al. 2014; Higham et al. 2006, 2011; Whittle et al. 
2008). Since its initial use in archaeology (Buck et al. 1996), Bayesian modeling has steadily gained popularity as OxCal (Bronk Ramsey 2001, 2009a) has become widely available and straightforward to operate.

The decisions an archaeologist makes while working with Bayesian models are far from simple, particularly when faced with complex stratigraphy or a significant proportion of "outlier" dates with various possible causes (Bayliss \& Bronk Ramsey 2004). Under such circumstances, a thorough account of these decisions, and the logic underlying them, is essential (Bayliss 2015).

We decided to use Bayesian models to calibrate the radiocarbon dates at Mochena Borago Rockshelter for two primary reasons. First, we hoped to identify potentially-outlying radiocarbon samples that may complicate the BXA's Pleistocene chronological sequence, to assist examinations of site formation and post-depositional processes. Second, we aimed to refine age estimates for the major lithostratigraphic units, to better assess how technological change at Mochena Borago fits into regional chronologies for MIS 3. To achieve these objectives, we first ran an initial model to help flag outlier dates, and then created a second, "cleaner" model that generated more precise estimates of the major chronostragraphic units of the rockshelter. Codes for these models are presented in Supplementary Data Table B (initial model) and Supplementary Data Table C (clean model).

We used OxCal version 4.2 to construct and fit our Bayesian chronological model with IntCal13 as the calibration curve (Bronk Ramsey 2009a; Reimer et al. 2013). We used default parameters for OxCal operation in most cases, and built the model to include a 5\% probability that any sample might be an outlier. All of the age ranges from our models are reported with 95.4\% confidence intervals, including estimates for the beginning and ending of each major chronostratigraphic unit. Estimated means and standard deviations are also reported.

\subsection{Principles of Bayesian modeling}

Over the past five decades, scholars have continually refined the calibration of radiocarbon dates to compensate for fluctuations of atmospheric radiocarbon (Suess 1967; Aitken 1990; Weninger \& Joris 2008; Reimer et al. 2013). However, calibrating dates individually - without a model that uses internal logic to impose constraints - can lead to needless imprecision due to statistical scatter (Bayliss 2009: 130-132).

Bayesian modeling incorporates known stratigraphic relations between different radiocarbon samples into the calibration process, thereby improving precision (Buck et al. 1996: 215-218). By using stratigraphic evidence to model groups of radiocarbon dates into a relative chronology, the Bayesian approach can achieve narrower age ranges for individual dates within a sequence, and generate "simulated ages" for specific events during a site's formation, such as the beginning or end of a particular stratigraphic unit (Bayliss 2009). It therefore provides the most benefit when applied to chronological sequences with direct stratigraphic links.

\subsection{Application of Bayesian modeling to BXA Pleistocene deposits}

Within the BXA, three contiguous $1 \mathrm{~m}^{2}$ excavation squares (G10, G9, H9) contain six major Late Pleistocene lithostratigraphic units distinguished by obvious differences in the constituents and color of matrix and/or inclusions. Two of these are virtually sterile layers (YBT, YBS) that mark volcanic events. The other four major lithostratigraphic units (Lower T-Group, Upper T-Group, S-Group, and R-Group) have evidence for human occupation. These six major units, contiguous across excavation squares, are ideal "phases" that can be used to constrain a Bayesian model. (Minor stratigraphic subunits - which have more subtle distinctions, are non-contiguous, and 
therefore sometimes have ambiguous stratigraphic relations to each other - should not be used in this way.)

Bayesian modeling can establish concrete age estimates for each major lithostratigraphic group and volcanic event. This will clarify the late Pleistocene archaeology of Mochena Borago in several respects. First, it creates a secure chronological interval within which more localized site formation processes can be reconstructed (e.g. Meyer et al. n.d.). Second, it can establish precise ages for "benchmark" strata (such as YBT and YBS) that may be found in noncontiguous excavation units elsewhere in the rockshelter. Third, age ranges for major lithostratigraphic units will aid in the dating of specific activities and behavioral changes at Mochena Borago, especially changes in stone tool technology.

Our application of Bayesian modeling to Mochena Borago began by using the contiguous strata documented within the BXA to constrain models for ages. In our model, each major lithostratigraphic unit (e.g., Upper T-Group) was a discrete phase, and consecutive stratigraphic units were consecutive phases (Lower T-Group deposition must precede Upper T-Group deposition).

Before attempting to run the model, we were forced to exclude two dates (Table 2, thirdlast column). Samples SWAP12-02 and SWAP12-05 both yielded ${ }^{14} \mathrm{C}$ ages $>49 \mathrm{ka}$. Because the samples had sufficient carbon mass after burning, the infinity dates most likely reflect the fact that the samples are older than the limits of radiocarbon dating. Such dates cannot be calibrated and therefore cannot be accommodated in a Bayesian model for radiocarbon.

\subsection{Detecting outliers, and modeling their probabilities}

Bronk Ramsey (2009b) defines four different types of problems affecting radiocarbon dates: $\mathrm{S}$, $\mathrm{R}, \mathrm{D}$, and T. Type $\mathrm{S}$ errors result from incorrect measurement of the ${ }^{14} \mathrm{C}$ sample; reported lab errors, which typically follow a normal distribution around a central age estimate, might not accurately reflect the possible variance in true age. Type $\mathrm{R}$ errors result from reservoir effects such as marine offsets, carbon recycling in lacustrine organisms, or ingestion of dead carbon for ostrich eggshell formation; these yield dates that are older than expected for the context. Type D errors occur across a group of samples, when multiple individual dates derived from similar or related sources are collectively subject to errors of Type S or Type R. Type T anomalies are not errors but outliers, which reflect a mismatch between the event being dated and the sample being measured. These can occur in two ways: the material being dated may belong to the context but ultimately derive from an earlier time (old wood), or postdepositional processes may introduce material from later or earlier events into the context under examination (taphonomic).

Outliers - dates that deviate substantially from stratigraphically-based expectations become apparent at two different stages in Bayesian analysis. Some outliers manifest themselves by "crashing" the model: Their calibrated age ranges are so extremely incompatible with the stratigraphic phases the researcher built into model that OxCal simply refuses to complete it. The researcher then must either reconsider stratigraphic relations or, if those are solid, exclude the incompatible dates and re-attempt the model. Other outliers may be less extreme: Dates may be compatible enough with the model to allow it to run to completion. However, the model output statistics will show serious discrepancies between the dates' calibrated ages and those that the model predicted. Any decision to exclude a date must consider the outlier's possible causes.

Initial attempts to run the model failed due to extreme outliers in T-Group: Samples SWAP14-01, SWAP14-02, SWAP14-03, and SWAP14-09 all yielded dates that are much younger than those from overlying strata. Because these anomalous dates are all isolated within 
two closely related minor stratigraphic units (AED and AEC) in the northwest quadrant of excavation unit $\mathrm{H} 9$, we believe they are a Type $\mathrm{T}$ outlier caused by a postdepositional taphonomic event. We were forced to exclude all these samples in order for the initial model to run successfully (Table 2 , second to last column).

\subsection{Initial Bayesian modeling of phases in the Block Excavation Area (BXA)}

Our initial run of OxCal 4.2 proposed six successive phases representing the six major Pleistocene lithostratigraphic groups in the BXA: Lower T-Group, Upper T-Group, YBT, SGroup, YBS, and R-Group. It included all dates that were $<49 \mathrm{kbp}$ and allowed the OxCal run to complete (Table 2, second-last column). The model assumed that a clear boundary existed between each phase, and generated a series of probable age ranges for the start and end of each phase (95.4\% probability). Outputs for the initial model run appear as Fig. 4 (probability curves) and Supplementary Data Table D (data).

We then examined the model outputs for dates that might be classified as "outliers" based on various diagnostic criteria from OxCal: Agreement index (A), Convergence of the MarkovChain Monte Carlo algorithm (C), and Probability of not being an outlier (P) (Bronk Ramsey 2009b). Several dates looked dubious because of a low Agreement Index value $(A<60)$. Of these, however, only a few failed the MCMC convergence test $(\mathrm{C}<95 \%)$. We decided to exclude all of the MCMC failures. We then examined the spread of posterior probabilities of not being an outlier (P), and decided to exclude any date with $\mathrm{P}<50$. This excluded four additional dates beyond those already excluded for poor convergence. All other dates were included in the final, "clean" model (Table 2, final column). Details on the identification of each outlier are presented below; see also Fig. 4 and Supplementary Data Table D.

Lower T-Group dating samples included in the initial model were SWAP14-06 (P=98.0) and SWAP07-13 (P=96.8). Both could be included in the final model.

Upper T-Group samples included in the initial model were SWAP08-01 $(\mathrm{P}<0.1)$, SWAP14-07 ( $\mathrm{P}=88.5)$, SWAP14-08 ( $\mathrm{P}=85.5)$, SWAP07-12 ( $<<0.1)$, SWAP12-04 ( $\mathrm{P}=97.4)$, SWAP12-03 (P=61.2), and SWAP07-11 ( $\mathrm{P}=88.1)$. Samples 12-03 and 12-04 were modeled together as a single date because both should have the same calendar age as they were split from a single specimen and processed at separate labs. The initial model run revealed two outliers. SWAP 08-01 $(\mathrm{A}=5.5, \mathrm{C}=96.9, \mathrm{P}<0.1)$ is $>10,000$ years later than other Upper $\mathrm{T}$ dating samples; coming from the easternmost portion of square G10, we must consider that the taphonomic processes affecting substrata AEC and AED also operated here. SWAP 07-12 (A=5.3, C=96, $\mathrm{P}<0.1)$ is another likely Type $\mathrm{T}$ outlier, with an unmodeled age range several thousand years later than other dates in this lithostratigraphic group.

YBT yielded five radiocarbon samples, all of which were included in the initial model: SWAP08-02 (P=77.8), SWAP14-05 (P=98.5), SWAP14-04 (P=98.6), SWAP07-09 (P=97.5), and SWAP08-03 $(\mathrm{P}<0.1)$. The model run revealed one Type T outlier: SWAP08-03 ( $\mathrm{A}=5.5$, $\mathrm{C}=98.8, \mathrm{P}<0.1)$ from near the top of $\mathrm{YBT}$, has a date that is younger than expected.

S-Group had three samples that could be included in the model, which yielded highly variable calibrated age ranges. SWAP07-07 $(A=14, C=97.9, P=40.1)$ is much younger than the model predicts from other samples in its depositional groups, and thus may represent an intrusion. The remaining two samples - SWAP12-01 (P=78.6) and SWAP08-04 (P=87.7) - have age ranges older than expected, but $\mathrm{P}$ indices high enough to be retained for the final model. The marked variation in S-Group dates is not surprising given fluvial activities documented during 
excavation. Phase modeling for S-Group is heavily constrained by neighboring strata (YBT below, and YBS above) each of which has an internally consistent set of dates.

YBS deposits yielded three samples that could all be included in the initial model:

SWAP14-12 (P=41.4), SWAP14-13 (P=91.4), and SWAP08-09 ( $\mathrm{P}=97.6)$. SWAP14-12 (A=26.7, $\mathrm{C}=90, \mathrm{P}=41.4$ ) is a Type $\mathrm{T}$ outlier (too young, likely intrusive material).

R-Group deposits furnished 11 dates that were all included in the initial model:

SWAP07-06 ( $\mathrm{P}=0.8)$, SWAP08-05 ( $\mathrm{P}=37.9)$, SWAP14-11 ( $\mathrm{P}=96.6)$, SWAP10-01 ( $\mathrm{P}=96.8)$, SWAP07-05 ( $\mathrm{P}=96.6)$, SWAP08-12 ( $\mathrm{P}=97.3)$, SWAP08-10 ( $\mathrm{P}=91.8)$, SWAP07-3 (P=94.4), SWAP08-08 (P=62.4), SWAP08-07 (P=97.1), SWAP08-11 ( $\mathrm{P}=97.3)$. The initial model identified two outliers that yielded unexpectedly old age ranges: SWAP 08-05 ( $\mathrm{A}=14.7, \mathrm{C}=91.4$, $\mathrm{P}=37.9)$ and SWAP 07-06 $(\mathrm{A}=5.4, \mathrm{C}=91.6, \mathrm{P}=0.8)$. They are from the same excavation unit and level.

Although it is unusual for post-depositional processes to introduce older materials, we are considering at least four possible causes for Type $\mathrm{T}$ outliers in cases where the charcoal ${ }^{14} \mathrm{C}$ ages may be older than the strata they were recovered from:

1. In the eastern area of the rockshelter, excavation units N42E35 and N42E36 have exposed strata ${ }^{14} \mathrm{C}$ dated on charcoal to $>49$ ka that are higher in elevation than BXA's T, YBT and S-Group deposits. Therefore, material from such deposits, including charcoal, could have been dislodged and displaced into the BXA through colluvial, fluvial, or erosional processes, and/or bioturbation or anthropogenic activities.

2. P. Goldberg (pers. comm.) and Meyer et al. (n.d.) allude to several likely episodes of water saturation within the BXA sequence (e.g., ponding and slow-moving streams) that may have caused the loosening or erosion of sediments. In such circumstances, lower and older strata may have released charcoal into the water, and charcoal may have floated to the surface and redeposited at the contact between the water surface and younger deposits.

3. Within the BXA, vertical transport of charcoal could have occurred through bioturbation, including burrowing by insects, crabs (unearthed during excavations) and rodents and other small mammals.

4. Similarly, humans could have disrupted depositional sequences by creating hearths or digging artificial pits, thereby moving long-buried material onto a younger occupational surface.

\subsection{Final Bayesian modeling of phases for BXA sequence, with outliers removed} Having identified major outliers and evaluated their possible causes, we follow Bronk Ramsey's (2009b) suggestion to run a "clean" version of the Bayesian model using dates that both satisfy recommended convergence values and also have $>50 \%$ probability of having ages that reflect the age of their major stratigraphic group (Table 2, final column). Outputs for the final model appear in Fig. 5 (probability curves for modeled dates and phases) and Table 3 (supporting data, including mean and standard deviation estimates for each date). Final age ranges (95.4\% probability) for the start and end dates of each major stratigraphic group are summarized and compared to earlier weighted mean calculations in Table 4.

\section{Discussion}

Initial publication of the BXA Late Pleistocene sequence was based upon five seasons of excavation, 22 radiocarbon dates, and the use of weighted means to express likely age ranges for major lithostratigraphic units (Brandt et al. 2012; Fisher 2010). Since then, four more field 
seasons, 15 new dates and additional analytical methods have considerably expanded our knowledge base. In the following sections we provide an overview for each major stratigraphic group of the ways in which Bayesian modeling has permitted us to: 1) revise previous age ranges; 2) identify and consider potential causes of outlier dates; and 3) reconsider old and develop new ideas concerning changes in lithic technology and other aspects of behavior.

1) Revised Age Range: Comparisons between weighted means and Bayesian age models are complicated by the fact that an "age range" derived from a weighted mean calculation represents a normal, unimodal distribution around a central point of maximum probability, whereas a phase's age range derived from Bayesian modeling incorporates two probability curves - one for the start of the phase, and one for its end - which are not necessarily normal. Therefore, for discussion purposes we have converted our previously published weighted mean ranges with 1-sigma errors (Brandt et al. 2012) into age ranges reflecting 2-sigma confidence intervals to allow for easier comparison. With the exception of the 2012 weighted mean calculations based on CalPal calibrations, all ${ }^{14} \mathrm{C}$ dates mentioned in the following sections are calibrated using IntCal 13 unless otherwise noted.

2) Outliers: Bayesian modeling provides a statistical rather than "cherry picked" reason for rejecting certain dates, and can serve as a starting point for discussions about why particular samples yield dates that deviate from expected values. Single to multiple processes merit consideration as potential causal mechanisms: 1) bioturbation (e.g., via root growth or animal burrowing); 2) mechanical displacement (e.g., fluvial or colluvial action); 3) chemical processes (e.g., leaching of original carbon or contamination with carbon from a different source); 4) geoturbation (e.g., eroded or reworked sediments); and 5) human activities (e.g., pits or substructures) (Meyer et al. n.d; Taylor \& Bar-Yosef 2014). Detailed hypotheses and explanations for outlier causes are beyond the scope of this article, but below we offer initial suggestions designed to galvanize future research.

3) Lithic Technological Change: Brandt et al. (2012) observed that some lithic patterns underwent incremental change (e.g., small changes in raw material preferences, slight deviations in the dominance of Tabular SDM core reduction strategies), while others remained at stasis for 20,000 years (e.g., retention of Levallois core reduction at low frequencies). Therefore, revising BXA's chronology cannot fundamentally reshape our current ideas about temporal changes in lithic technology. Instead the new chronology gently stretches the temporal frame, suggesting that continuities and changes in lithic technology spanned a longer period than previously thought. Because the modeled age ranges reveal the true degree of uncertainty about "start" and "end" dates for major phases, they may inject a much-needed note of caution into efforts to pinpoint dates for specific innovations, or correlate particular behavioral changes with external shifts in environment. Nevertheless, a few significant technological developments require updating in light of revised age ranges and continued lithic analyses of BXA assemblages since 2012.

\subsection{Lower T-Group: >50 ka to 49.9-47.8 ka.}

Revised Age Range: The single date available in 2012, calibrated by CalPal to 2-sigmas, indicated a range of 58.4-48.0 ka for Lower T-Group. Unfortunately research since then has not led to any greater precision in defining the beginning of T-Group deposition, as $20-30 \mathrm{~cm}$ of sediments at the base of Lower T-Group still remain undated due to the absence of charcoal. We can only conclude that Lower T-Group deposits began to accumulate both through natural and human-derived events sometime before $50 \mathrm{ka}$. Our Bayesian model (now based on two dates) 
suggests that Lower T-Group deposition ended between 49.9 and $47.8 \mathrm{ka}$, which is reasonably concordant with weighted mean calculations.

Outliers: Three ${ }^{14} \mathrm{C}$ dates of $\sim 31 \mathrm{ka}, \sim 39 \mathrm{ka}$ and $\sim 41 \mathrm{ka}$ from sub-stratum AED in Unit H9 indicate that a postdepositional event - possibly bioturbation - brought small pieces of charcoal and perhaps other material down into certain strata within Lower T-Group. Although lithics from the sub-stratum encompassing the intrusive charcoal (AED) are fresh and show no signs of abrasion, planned lithic studies will isolate these from the other Lower T-Group assemblages for comparative purposes.

Lithic Technological Change: The lithics from Lower T-Group, and for that matter all the stratigraphic groups at Mochena Borago, share a distinctive combination of core reduction strategies, tool types and other artifacts, that do not match any other known site in the Horn of Africa. Nor is this combination easy to place within traditional culture-historic stages such as the MSA or LSA (Brandt et al. 2012). For example, despite the presence of Nubian cores and points in the T-Group and overlying deposits, it is unlikely that Mochena Borago's lithic tradition derives from the Nubian Complex. The origin of Mochena Borago's distinct lithic tradition remains unknown until further excavations at Mochena Borago or other sites in the region can provide sequences chronometrically dated to earlier than $50 \mathrm{ka}$.

Recent analyses of previously unstudied Lower T-Group assemblages have documented backed pieces for the first time (R. Vogelsang pers. obs.). Ranging from >50 to $48 \mathrm{ka}$ in age based on the Bayesian model, these backed pieces, albeit few in number, represent the oldest securely dated evidence for purposeful blunting of flake and blade edges in the Horn. Whether backed pieces served as arrow armatures is a subject of great debate. The recent discovery of plant and animal residues as well as traces of use wear on > 200 artifacts from Lower and Upper T-Groups, including backed pieces, promises to shed new light on the functions of stone tools >50-40 ka (C. Lentfer and V. Rots pers. comm.).

\subsection{Upper T-Group: 49.4-47.4 ka to 48.0-45.7 ka}

Revised Age Range: Weighted mean calculations from the three dates available in 2012 yielded a 2-sigma range of 47.1-43.2 ka for Upper T-Group. Bayesian modeling suggests a start date sometime between 49.4 and $47.4 \mathrm{ka}, 2000$ years earlier than previously thought. End dates for Upper T-Group, modeled as 48.0-45.7 ka, are at least 2500 years earlier than the youngest age anticipated by weighted means.

Outliers: Two dates of $\sim 30.5 \mathrm{ka}$ and $\sim 28 \mathrm{ka}$ (unmodeled IntCal calibration; see Supplementary Data Table A) are significantly younger than expected, and were rejected by the Bayesian model. These were probably intrusive due to one or more of the aforementioned potential causes. The single date of $>49 \mathrm{ka}$ within Upper T-Group is too old to be incorporated into the Bayesian model, and also constitutes an outlier. Section 4.4 discusses potential causes for unexpectedly old dates.

Lithic Technological Change: Lithics from Upper T-Group show many of the same characteristics as those in Lower T-Group. Unifacial and bifacial points made mostly on elongated flakes from Tabular SDM cores still form the highest percentage of shaped tools, but backed pieces now represent the second highest percentage at the expense of points. Although sample sizes are small, it is temping to view these shifts in frequency as reflecting changing perspectives on the importance of points vs. backed tools as composite tool armatures.

\subsection{YBT tephra: $46.9-45.5 \mathrm{ka}$ to $46.4 \mathrm{ka}-45.4 \mathrm{ka}$}


Revised Age Range: In 2012, weighted mean calculations from three dates suggested that deposition of this tephra occurred sometime between 45.8-41.0 ka. Bayesian modeling suggests a start date sometime between 46.9 and $45.5 \mathrm{ka}$, and an end date sometime between 46.3 and 45.2 ka. Because tephra deposition was probably a very brief event (i.e. start and end dates for this tephra should be $<100$ years apart) we can narrow the range further: YBT deposition probably started after $46.4 \mathrm{ka}$, and ended by $45.4 \mathrm{ka}$.

Outliers: Dates are mostly consistent through YBT, as one might expect in a tephra. However its upper reaches have one outlier ( 42.5-40 ka, unmodeled IntCal calibration) that suggests contamination from later fluvial processes. This has little impact on artifact analysis, because YBT is for all practical purposes archaeologically sterile.

\subsection{S-Group: $46.1-45.4$ ka to $45.8-43.9 \mathrm{ka}$}

Revised Age Range: Weighted mean calculations from three dates in 2012 had given a 2sigma range of 44.3-42.6 ka for S-Group. Bayesian modeling suggests a start date sometime between 46.1 and $44.8 \mathrm{ka}$, again allowing for a substantially earlier onset. The brief nature of YBT deposition might argue for an even narrower and earlier S-Group start range (i.e. 46.1-45.4 $\mathrm{ka}$; however this would assume that S-Group reoccupation followed immediately on the heels of the YBT eruption, which is unlikely given the major unconformity on the YBT/S-Group interface. End dates for S-Group, modeled as 45.8-43.9 ka, are at least 1200 years earlier than the youngest age anticipated by weighted means.

Outliers: Since the charcoal dating to 43.8-42.3 ka (unmodeled IntCal calibration) was eliminated from the model, this sample should be considered intrusive. Whether it originated from overlying YBS, or less likely R-Group deposits, or was brought in via the paleofluvial channel, remains uncertain. The charcoal dating to $>49$ ka represents the uppermost sample beyond calibration, and within the context of S-Group must be seen as an outlier.

Lithic Technological Change: S-Group lithics reveal a number of important differences with the earlier T-Group assemblages. Whereas T-Group lithics are virtually all fresh, S-Group deposits witness a significant increase in the number and percentage of lithics with varying degrees of abrasion and rolling indicative of geoturbation. Nevertheless, more than 80 percent are fresh and nearly $100 \%$ are obsidian - another change from the T-Group where assemblages always maintain a very low but consistent percentage of non-volcanic or silicious artifacts. The significant increase in the frequency of bipolar cores in the S-Group is one of the more notable changes in the BXA archaeological sequence. Why this technology is more prevalent in S-Group assemblages is not yet understood, particularly when knappers presumably had access to excellent, plentiful obsidian from Baantu and perhaps other sources. Research into African bipolar reduction strategies has recently experienced a surge in interest (e.g. Hiscock 2015), and plans are afoot to develop more detailed studies of Mochena Borago samples in future seasons.

\subsection{YBS mudflow: 44.9-43.1 ka to 43.7-42.3 ka}

Revised Age Range: The single date available for YBS in 2012, calibrated by CalPal, had suggested that deposition of this pyroclastic mudflow occurred sometime between 44.5-41.8 ka. Bayesian modeling suggests a start date sometime between 44.9 and $43.1 \mathrm{ka}$, and an end date sometime between 43.7 and $42.3 \mathrm{ka}$. Like YBT, the YBS mudflow probably spanned a period of $<100$ years, so its deposition should not have started before $43.8 \mathrm{ka}$, and should not have ended after $43.0 \mathrm{ka}$. 
Outliers: During the YBS mudflow, fluvial processes brought natural material into the rockshelter. There was thus potential for pre-existing archaeological material to have been picked up by the mudflow and integrated into YBS, but this did not happen: YBS contains only a few lithics, and the sole statistical outlier among its dating samples is only slightly too young. Its age range (42.5-41.8 ka via unmodeled IntCal calibration) still overlaps with the YBS's overall modeled age range.

\section{6. $R$-Group: 43.1-42.0 ka to 39.6-36.6 ka}

Revised Age Range: In 2012, weighted mean calculations from 11 dates suggested a 2-sigma range of 42.7-39.6 ka for R-Group. Bayesian modeling produces a start date sometime between 43.1 and $42.0 \mathrm{ka}$, roughly in line with the weighted mean. End dates, modeled as 39.6-36.6 ka, allow R-Group deposition to continue 3000 years later than anticipated by weighted means.

Outliers: R-Group deposits contain a puzzling pair of outliers that are older than the model suggests (46.1-44.0 ka and 46.0-42.6 ka, unmodeled IntCal calibrations). There is no evidence for bioturbation that would have transported materials up from deeper layers within the BXA. However, recent excavations in eastern parts of the shelter have revealed earlier deposits at higher elevations, from which charcoal could have moved laterally and down into the BXA during wet or erosional episodes. Future work in eastern Mochena Borago will clarify its chronology and examine the possibility of such transport.

Lithic Technological Change: R-Group lithics are reported here for the first time as they were not discussed in Brandt et al. 2012. One of the biggest and most puzzling aspects of its assemblages is the very high percentage of lithics that show some degree of abrasion or rolling more than 65\%! But the R-Group's matrix reveals little if any evidence for high-velocity fluvial action - the usual cause of artifact erosion. How, then, could only a third of the lithics be fresh? Or, conversely, why aren't all of the lithics abraded or rolled? Recent studies of the R-Group (and S-Group) assemblages have begun to address this question by giving special emphasis to analytically differentiating fresh vs. abraded artifacts (Bermensolo 2013; Parow-Souchon et al. n.d). Future research will use 3-D plot data to look for spatial and temporal patterns of fresh vs. damaged artifacts in a GIS framework.

Bayesian modeling has unexpected implications for the damaged condition of many R-Group lithics, when considered alongside the major unconformity and temporal hiatus of $>26,000$ years separating the youngest R-Group sediments from the early Holocene BWT tephra. Mochena Borago finds a parallel at Goda Buticha Cave, the only other Ethiopian site with stratified, chronometrically dated archaeological deposits spanning the last half of the Late Pleistocene. Goda Buticha's 48,000 year sequence is also disrupted by a major depositional and occupational gap from $\sim 35 \mathrm{ka}$ to $\sim 8 \mathrm{ka}$ (Pleurdeau et al. 2014). Weighted means (Brandt et al. 2012) had placed the latest levels of R-Group at $\sim 40 \mathrm{ka}, 5000$ years earlier than the beginning of Goda Buticha's hiatus. Our new modeled age ranges reposition Mochena Borago's hiatus from $\sim 36 \mathrm{ka}$ to $\sim 8 \mathrm{ka}$, now making it contemporary with Goda Buticha's hiatus. Although so far only two sites demonstrate this Late Pleistocene depositional gap, we propose the working hypothesis that it corresponds to a sudden, major regional climatic event, in which arid and cold conditions triggered human demographic shifts and abandonment of some sites prior to the onset of the MIS 2 and the LGM.

\subsection{A collective consideration of outliers}


Of the 37 dates obtained thus far for BXA Late Pleistocene deposits, 24 are consistent with the framework of the model and the overall stratigraphic sequence. Thirteen dates appear to be outliers, and it may be useful to discuss the extent to which these can be grouped into discrete events, episodes, or processes. Some of these may relate to observed formation processes, but others may relate to undetectable taphonomic events or even reflect sample contamination that could not be cleared via the gentle ABA preparation necessitated by small sample size.

Reviewing possible explanations for particular sets of outliers, we can dismiss some and retain others for further investigation.

Lower and Upper T-Group deposits yielded five outliers (SWAP14-02, SWAP14-03, SWAP14-09, SWAP18-01, and SWAP14-01) and possibly a sixth (SWAP07-12) (Table 2). These five dates are much younger than their neighbors - a difference greater than 10,000 years! One possible explanation is sample contamination, but even if samples had been of sufficient size to use a more aggressive pretreatment regimen (e.g., ABOx) it is not clear whether this degree of discrepancy could be remedied - and even if it could, one would also have to explain why such contamination affected this group of samples so selectively. Because the five samples are from two adjacent minor strata that are spatially circumscribed, it is reasonable to suggest that a unified set of intrusive processes is responsible for bringing younger material into this specific area.

The two dates $>49{ }^{14} \mathrm{C}$ bp - which were never modeled because they are beyond the age of calibration - are also outliers. If such dates had appeared in the lower reaches of Lower TGroup, this would be consistent with expectations, but SWAP12-05 is in Upper T-Group, and SWAP12-02 is in S-Group. How did material $>49{ }^{14} \mathrm{C}$ ka get incorporated into these contexts? Upward transport of charcoal via bioturbation or human activity from the undated lower reaches of Lower T-Group is unlikely, given that these layers yielded no charcoal despite intense recovery efforts. Just below this, PKT - BXA's basal stratum consisting of thick, hard volcanic deposits - is similarly bereft of charcoal. In the event that as-yet-undiscovered anthropic layers exist even farther below, transport across PKT is unrealistic. Given the improbability of local transport within the BXA, we must consider other parts of Mochena Borago as potential sources for this charcoal. Eastern parts of the rockshelter have strata $>49 \mathrm{ka}$ in age at higher elevations. It is possible that erosion or human activities may have caused the lateral transport of materials in a way that deposited old charcoal fragments from eastern Mochena Borago on a younger surface within the BXA. This is particularly likely for S-Group, where a paleofluvial channel has been observed. In light of this, Upper T-Group's substratum that yielded the other $>49$ ka date merits further examination.

The remaining five outliers differ from modeled age ranges by $<5000$ years (Supplementary Data Table D). These smaller discrepancies might be due to formation processes and/or in-sample contamination. If sample contamination existed, more aggressive pretreatment could possibly have resolved the age difference. But this is purely speculative, as samples were too small for ABOx and/or pyrolysis pretreatments. Explanations that relate to formation processes must be considered so they can be evaluated during future fieldwork.

Two of the five (SWAP07-06 and SWAP08-05) are from lower portions of R-Group. These anomalously early dates are so similar and spatially proximate that they may be examined together (Table 2). Local bioturbation (transport up from S-Group within the BXA) is possible, although we did not see any visual evidence of S-Group's more coarse-grained, pale, yellowish strata in this area. Another possibility - renewed lateral transport from eastern parts of the rockshelter - may be more probable, given that other observations point to standing water (which 
must have come from elsewhere), intermittent deposition and erosion episodes, and post-discard movement and damage to many R-Group lithics.

The remaining three outliers (SWAP08-03 in YBT, SWAP07-07 in S-Group, and SWAP14-12 in YBS) are each isolated cases in which a date is younger than expected and deviates from modeled age ranges by less than 5000 years. These could be accounted for either via individual contamination, or small-scale bioturbation events that might escape an excavator's notice.

\section{Conclusion}

Bayesian modeling, coupled with an enhanced array of radiocarbon dates, reshapes our view of the late Pleistocene chronology of the BXA within Mochena Borago Rockshelter in subtle but important ways. In some cases (e.g. YBT and YBS), the use of stratigraphic relationships to constrain the variability of dates has indeed generated more precise age ranges than the weighted mean model (cf. Bayliss \& Bronk Ramsey 2004). As excavation proceeds outside the BXA, having these "benchmark" strata may lend precision to sequences in other parts of the shelter. In other cases (S-Group), stratigraphic constraints provided more of the modeled information than the stratigraphic unit's individual dates themselves, all of which had low Agreement Index values $(\mathrm{A}<60)$. This showcases another benefit of the Bayesian model: highlighting inconsistencies between modeled expectations and collected data. R-Group demonstrates the benefits of modeling age boundaries directly rather than estimating a single central tendency, as individual dates appear to cluster into two groups: six dates $>40 \mathrm{ka}$ and six $<40 \mathrm{ka}$ (Fig. 4).

Mochena Borago's significant number of outlier dates stems in part from Bayesian analysis' strict reliance on a stratigraphic model, such that residual or intrusive samples are highly likely to be identified as outliers. This positive development has practical consequences: either projects must become extremely selective in choosing dating samples (e.g., articulated faunal or human remains, structures, or other demonstrably intact features) whose contexts are so secure that the possibility of getting an outlier date is minimal (Bayliss 2015:689), or projects must obtain a large number of dates (Douka et al. 2014) from reliable material (e.g., charcoal) that has been piece-plotted so as to allow iterative refinements in the stratigraphic model.

Research at Mochena Borago illustrates the benefits of the latter strategy. Finding outliers stimulates much-needed reflection about the contextual integrity of the Late Pleistocene assemblages from the BXA, and suggests complicated site formation processes that may involve multiple areas of the site. Rockshelters, including Ethiopian examples such as Porc-Épic (Assefa 2006), are well-known for having complicated stratigraphy. Results presented here show the importance of painstaking methods applied over years of excavation and analysis (e.g., Marean 2010). Only an exhaustive dating program could provide enough data points to distinguish between main depositional events and post-depositional processes. Individual piece plotting for all charcoal samples and most artifacts since 2006 will allow us to develop and implement criteria for separating primary vs. secondary contexts, and natural vs. cultural formation processes as we untangle the threads of Mochena Borago's complex depositional history.

Lithic technological data from Mochena Borago, now situated in a revised chronological framework, provide several insights into questions related to dispersals. The discovery of backed pieces in the deepest levels of Lower T-Group's undated sediments just above PKT suggests that this hafting strategy was practiced in SW Ethiopia closer to $60 \mathrm{ka}$ rather than $50 \mathrm{ka}$, when huntergatherers began their early MIS 3 range expansion. It remains to be seen whether backing 
appeared even earlier in MIS 4, but as excavations outside the BXA penetrate recently discovered older strata (S. Brandt pers. obs.), Mochena Borago may help settle this question.

Obtaining precise ages for strata $>50 \mathrm{ka}$ will be challenging because of the impracticability of luminescence dating in areas exposed to volcanic activity. However, the planned establishment of a detailed tephrochronology for Mt Damota and surrounding areas, combined with renewed attempts at argon dating, is one way to tackle this problem. Another is Obsidian Hydration Dating (OHD), which has not been used in Africa for decades because of reliability issues (Anovitz et al. 1999). New and refined methods of OHD are now being tested on obsidian artifacts from Mochena Borago specifically because of the site's well-dated sequence (C. Stevenson pers. comm), which through the new age model has now been made even more secure.

One of the most striking aspects of Mochena Borago's cultural sequence is the longstanding maintenance of many core reduction strategies, including Levallois, right up to the stratigraphic hiatus beginning $\sim 36 \mathrm{ka}$. Considering the rapid, dramatic climate oscillations of

MIS 3, punctuated by major, possibly catastrophic volcanic events, such technological continuity is remarkable. It attests to strategies that were flexible enough to accommodate the unexpected. Indeed, for more than twenty millennia on Mt. Damota, "plus ça change, plus la même."

\section{Acknowledgments}

We thank the Ethiopian Authority for Research and Conservation of Cultural Heritage, the Southern Nations, Nationalities and Peoples Regional Government Bureau of Culture and Tourism, the Wolaita Zone Bureau of Culture and Tourism, Wolaita Sodo University and our government representatives for facilitating fieldwork and museum studies. We also thank the many Ethiopian, German and American students and colleagues, and especially Minassie Girma, Kylie Bermensolo and Hannah Parow-Souchon, who participated in and/or provided assistance in field and laboratory work. Thanks to Oliver Bödeker, Svenja Meyer, and George Brook for their many inputs and insights concerning the geomorphology of the area. We are very grateful to Erich Fisher for his contributions to the success of our field, laboratory and analytical endeavors. Funding was provided by the Deutsche Forschungsgemeinschaft (CRC 806), US National Science Foundation (BCS \#0553371), the University of Florida International Center and the UF College of Liberal Arts and Sciences. Finally we thank the people of Wolaita, and in particular the local residents of Mt. Damota for their participation and support in field research. 


\section{Bibliography}

Aitken, M.J. 1990. Science-based Dating in Archaeology. Longman: London.

Anovitz, L.M., Elam, M., Riciputi, L., Cole, D. 1999. The failure of obsidian hydration dating: sources, implications, and new directions. Journal of Archaeological Science 26, 735-752.

Armitage, S.J., Jasmin, S.A., Marks, A.E., Parker, A.G., Usik, V.I., Uerpmann, H.-P., 2011. The southern route "Out of Africa": evidence for an early expansion of modern humans into Arabia. Science 331, 543-456.

Assefa, Z., 2006. Faunal remains from Porc-Epic: Paleoecological and zooarchaeological investigations from a Middle Stone Age site in southeastern Ethiopia. Journal of Human Evolution 51, 50-75.

Bayliss, A. 2009. Rolling out revolution: using radiocarbon dating in archaeology. Radiocarbon 51(1), 123-147.

Bayliss, A. 2015. Quality in Bayesian chronological models in archaeology. World Archaeology 47(4), 677-700.

Bayliss, A., Brock, F., Farid, S., Hodder, I., Southon, J., Taylor, R. E., 2015. Getting to the bottom of it all: a Bayesian approach to dating the start of Çatalhöyük. Journal of World Prehistory 28(1), 1-26.

Bayliss, A., Bronk Ramsey, C. 2004. Pragmatic Bayesians: a decade of integrating radiocarbon dates into chronological models. In: Buck, C.E., Millard, A. (Eds.), Tools for Constructing Chronologies: Crossing Disciplinary Boundaries. Springer, London, pp. 25-41.

Benazzi, S., Douka, K., Fornai, C. Bauer, C., Kullmer, O., Svoboda, J., Pap, I., Mallengi, F., Bayle, P., Coquerelle, M., Condemni, S., Ronchitelli, A., Harvati, K., Weber, G. 2011. Early dispersal of modern humans in Europe and implications for Neanderthal behaviour. Nature 479, $525-528$.

Bermensolo 2013. Flaked stone artifacts from the R-Group at the Mochena Borago Rockshelter, Ethiopia, and their implications. Unpublished M.A. qualifying paper on file, University of Florida, Gainesville.

Bird, M.I., Ayliffe, L.K., Fifield, L.K., Turney, C.S.M., Cresswell, R.G., Barrows, T.T., David, B., 1999. Radiocarbon dating of "old" charcoal using a wet oxidation, stepped-combustion procedure. Radiocarbon 41(2), 127-140.

Brandt, S.A., 1986. The upper Pleistocene and early Holocene prehistory of the Horn of Africa. African Archaeological Review 4, 41-82. 
Brandt, S.A., Brook, G.A., 1984. Archaeological and paleoenvironmental research in Northern Somalia. Current Anthropology 25 (1), 119-121.

Brandt, S.A., Gresham, T.H., 1989. L'age de la pierre en Somalie. L'Anthropologie 94 (3), 459482.

Brandt, S., Weedman, K. 2002. Woman the toolmaker. Archaeology 55(5), 50-53.

Brandt, S.A., Fisher, E.C., Hildebrand, E.A., Vogelsang, R., Ambrose, S.H., Lesur, J., Wang, H. 2012. Early MIS 3 occupation of Mochena Borago Rockshelter, Southwest Ethiopian Highlands: Implications for Late Pleistocene archaeology, plaeoenvironments and modern human dispersals. Quaternary International 274, 38-54.

Brock, F., Higham, T., Ditchfield, P., Bronk Ramsey, C., 2010. Current pre-treatment methods for AMS radiocarbon dating at the Oxford Radiocarbon Accelerator Unit (ORAU). Radiocarbon $52,103-112$.

Bronk Ramsey, C. 2001. Development of the radiocarbon calibration program OxCal. Radiocarbon 43, 355-363.

Bronk Ramsey, C., 2009a. Bayesian analysis of radiocarbon dates. Radiocarbon 51, 337-360.

Bronk Ramsey, C., 2009b. Dealing with outliers and offsets in radiocarbon dating. Radiocarbon 51(3), 1023-1045.

Buck, C.E., Cavanagh, W.G., Litton, C.D. 1996. Bayesian Approach to Interpreting Archaeological Data. John Wiley \& Sons, West Sussex.

Clark, J.D., Williamson, K.D. 1984. A Middle Stone Age occupation site at Porc Epic cave, Dire Dawa (east-central Ethiopia), Part I. African Archaeological Review 2, 37-64.

Diez-Martín, F., Domínguez-Rodrigo, M., Sánchez, P., Mabulla, A.Z.P., Tarriño, R.B., Prendergast, M.E., de Luque, L., 2009. The Middle to Later Stone Age technological transition in East Africa. New data from Mumba Rockshelter Bed V (Tanzania) and their implications for the origin of modern human behavior. Journal of African Archaeology 7, 147-173.

Douka, K., Jacobs, Z., Lane, C., Grün, R., Farr, L., Hunt, C., Inglis, R., Reynolds, T., Albert, P., Aubert, M., Cullen, V., Hill, E., Kinsley, L., Roberts, R., Tomlinson, E., Wulf, S., Barker, G. 2014. The chronostratigraphy of the Haua Fteah cave (Cyrenaical northeast Libya). Journal of Human Evolution 66, 39-63.

Drake, N., Breeze, P. 2016. Climate change and modern human occupation of the Sahara from MIS 6-2. In: Jones, S.C., Stewart, B.A., (Eds.), Africa from MIS 6-2: Population Dynamics and Paleoenvironments. Springer, Dordrecht, pp. 103-122. 
Drake, N.A., Breeze, P., Parker, A. 2013. Palaeoclimate in the Saharan and Arabian Deserts during the Middle Palaeolithic and the potential for hominin dispersals. Quaternary International $300,48-61$.

Fisher, E., 2010. Late Pleistocene Technological Change and Hunter-Gatherer Behavior at Moche Borago Rockshelter, Sodo-Wolayta, Ethiopia: Flaked Stone Artifacts from the Early OIS 3 (60-43 ka) Deposits. Unpublished PhD thesis, University of Florida, Gainesville.

Galbraith, R.F., Roberts, R.G., Laslett, G.M., Yoshida, H., Olley, J.M., 1999. Optical dating of single and multiple grains of quartz from Jinmium rock shelter, northern Australia, Part I: experimental design and statistical models. Archaeometry 41, 339-364.

Galbraith, R.F., Roberts, R.G., Yoshida, H., 2005. Error variation in OSL palaeodose estimates from single aliquots of quartz: a factorial experiment. Radiation Measurements 39, 289-307.

Gliganic, L.A.G., 2011. Optically and Infrared Stimulated Luminescence Investigations of the Middle and Later Stone Age in East Africa. Unpublished PhD thesis, University of Wollongong, Wollongong/Australia.

Goder-Goldberger, M. 2013. The Khormusan: Evidence for an MSA East African Industry in Nubia. Quaternary International 300, 182-194.

Gresham, T.H., 1984. An Investigation of an Upper Pleistocene Archaeological Site in Northern Somalia. Unpublished M.A. thesis. University of Georgia.

Gutherz, X., 2000. Sondages dans l'abri sous-roche de Moche Borago Gongolo dans le Wolayta (Ethiopie). Annales d'Ethiopie XVI, 35-38.

Gutherz, X., Jallot, L., Lesur, J., Pouzolles, G., Sordoillet, D., 2002. Les fouilles de l'abri sousroche de Moche Borago (Soddo, Wolyata), Premier bilan. Annales d'Ethiopie XVIII, 181-190.

Gutherz, X., Diaz, A., Ménard, C., Bon, F., Douze, K., Léa, V., Lesur, J., Sordoillet, D., 2014. The Hargeisan revisited: Lithic industries from shelter 7 of Laas Geel, Somaliland and the transition between the Middle and Late Stone Age in the Horn of Africa. Quaternary International 343, 69-84.

Haesaerts, P., Damblon, F., Nigst, P., Hublin, J-J., 2013. ABA and ABOx radiocarbon crossdating on charcoal from Middle Pleniglacial loess deposits in Austria, Moravia, and western Ukraine. Radiocarbon 55 (2-3), 641-647.

Henn, B.M., Botigué, L. R., Gravel, S., Wang, W., Brisbin, A., Byrnes, J.K., Fadhlaoui-Zid, K., Zalloua, P., Moreno-Estrada, A., Bertranpetit, J., Bustamante, C.D., Comas, D. 2012. Genomic ancestry of North Africans supports back-to-Africa migrations. PLOS Genetics 8, e1002397. 
Higham, T., Ramsey, C.B., Karavanic, I., Smith, F.H., Trinkaus, E. 2006. Revised direct radiocarbon dating of the Vindija G1 Upper Paleolithic Neandertals. Proceedings of the National Academy of Sciences USA 103(3), 553-557, doi:10.1073/pnas.0510005103.

Higham, T., Compton, T., Stringer, C., Jacobi, R., Shapiro, B., Trinkaus, E., Chandler, B., Gröoning, F., Collins, C., Hillson, S., O’Higgins, P., FitzGerald, P., Fagan, M., 2011. The earliest evidence for anatomically modern humans in northwestern Europe. Nature 479, 521524.

Higham, T., Brock, F., Peresani, M., Broglio, A., Wood, R., Douka, K., 2009. Problems with radiocarbon dating the Middle to Upper Palaeolithic transition in Italy. Quaternary Science Reviews 28, 1257-1267.

Hiscock, P. 2015. Making it small in the Palaeolithic: bipolar stone-working, miniature artifacts, and models of core recycling. World Archaeology 47(1), 158-169.

Hovers, E., 2006. Neanderthals and modern humans in the Middle Paleolithic of the Levant: what kind of interaction? In: Conard, N. (Ed.), When Neanderthals and Modern Humans Met. Kerns Verlag, Tubingen, pp. 65-86.

Hughen, K., Southon, J., Lehman, S., Bertrand, C., Turnbull, J., 2006. Marine-derived ${ }^{14} \mathrm{C}$ calibration and activity record for the past 50,000 years updated from Cariaco Basin. Quaternary Science Reviews 25, 3216-3227.

Jones, S., Antoniadou, A., Barton, H., Drake, N., Farr, L., Hunt, C., Inglis, R., Reynolds, T., White, K., Barker, G. 2016. Patterns of hominin occupation and cultural diversity across the Gebel Akhdar of Northern Libya over the last 200 kyr. In: Jones, S.C., Stewart, B.A., (Eds.), Africa from MIS 6-2: Population Dynamics and Paleoenvironments. Springer, Dordrecht, pp. $77-122$.

Karkanas, P., Brown, K.S., Fisher, E., Jacobs, Z., Marean, C.W., 2015. Interpreting human behavior from depositional rates and combustion features through the study of sedimentary microfacies at site Pinnacle Point 5-6, South Africa. Journal of Human Evolution 85, 1-21.

Klein, R. 2009. The Human Career, $3^{\text {rd }}$ Edition. University of Chicago Press, Chicago.

Knicker, H., Müller, P., Hilscher, A., 2007. How useful is chemical oxidation with dichromate for the determination of "Black Carbon" in fire-affected soils? Geoderma 142, 178-196.

Leplongeon, A. 2014. Microliths in the Middle and Later Stone Age of eastern Africa: new data from Porc-Epic and Goda Buticha cave sites, Ethiopia. Quaternary International 343, 100-116.

Leplongeon, A., Pleurdeau, D. 2011. The Upper Paleolithic lithic industry of Nazlet Khater 4 (Egypt): Implications for the Stone Age/Palaeolithic of Northeastern Africa. African Archaeological Review 28, 213-236. 
Marean, C.W., 2010. Introduction to the special issue: the Middle Stone Age at Pinnacle Point Site 13B, a Coastal Cave near Mossel Bay (Western Cape Province, South Africa). Journal of Human Evolution 59, 231-233.

Marks, A. 1968. The Khormusan: an Upper Pleistocene industry in Sudanese Nubia. In: Wendorf, F. (Ed.) The Prehistory of Nubia, vol. 1. Fort Burgwin Research Center and Southern Methodist University Press, Dallas, pp. 315-391.

McBrearty, S., Brooks, A. 2000. The revolution that wasn't: A new interpretation of the origins of modern behavior. Journal of Human Evolution 39(5), 453-563.

Mellars, P., 2006. Going East: new genetic and archaeological perspectives on the modern human colonization of Eurasia. Science 313, 796-800.

Mellars, P., Gori, K.C., Carr, M., Soares, P.A., Richards, M.B., 2013. Genetic and archaeological perspectives on the initial modern human colonization of southern Asia. PNAS 110 (26), 10699-10704.

Ménard, C., Bon, F., Dessie, A., Bruxelles, L., Douze, K., Fauvelle, F.-X., Khalidi, L., Lesur, J., Mensan, R. 2014. Late Stone Age variability in the Main Ethiopian Rift: New data from the Bulbula River, Ziway-Shala Basin. Quaternary International 343, 53-68

Ménard, C. 2015. Ruptures et continuités dans le Late Stone Age de la Corne de l'Afrique : apports des industries lithiques du Rift éthiopien. Unpublished $\mathrm{PhD}$ thesis, Université ToulouseJean Jaurès.

Mercier, N., Valladas, H., Froget, L., Joron, J.-L., Vermeersch, P.M., Van Peer, P., Moeyersons, J. 1999. Thermoluminescence dating of a Middle Palaeolithic occupation at Sodmein Cave, Red Sea Mountains (Egypt). Journal of Archaeological Science 26, 1339-1345.

Meyer, S., Bödeker, O., Fisher, E., Kehl, M., Brandt, S., Goldberg, P., Vogelsang, R., Zinaye, B., Bubenzer, O. in prep. Deciphering rockshelter evolution and sediment deposition in volcanic, mountainous, tropical humid landscapes: The case of Mochena Borago (Ethiopian Highlands). Submitted in May 2016 to Geoarchaeology - An International Journal.

Moeyersons, J., Vermeersch, P.M., Van Peer, P. 2002. Dry cave deposits and their palaeoenvironmental significance during the last 115 ka, Sodmein Cave, Red Sea Mountains, Egypt. Quaternary Science Reviews 21, 837-851.

Müller, U.C., Pross, J., Tzedakis, P.C., Gamble, C., Kotthoff, U., Schmiedl, G., Wulf, S., Christanis, K. 2011. The role of climate in the spread of modern humans into Europe. Quaternary Science Reviews 30, 273-279.

Parow-Souchon, H. 2013. Die Klingentechnologie von Mochena Borago / Äthiopien. Innovation vor 40.000 Jahren. Master's Thesis, University of Cologne. 
Parow-Souchon, H., Vogelsang, R., Brandt, S.A. n.d. Blade production at Mochena Borago Rockshelter, Ethiopia: A contribution to MIS 3 technological variability in the Horn of Africa. Manuscript in preparation.

Parton, A., Farrant, A.R., Leng, M.J., Schwenninger, J.-L., Rose, J.I., Uerpmann, H.-P., Parker, A.G. 2013. An early MIS 3 pluvial phase in Southeast Arabia: climatic and archaeological implications. Quaternary International 300, 62-74.

Pleurdeau, D., 2005. Human technical behavior in the African Middle Stone Age: the lithic assemblage of Porc-Epic cave (Dire Dawa, Ethiopia). African Archaeological Review 22, 177197.

Pleurdeau, D., Hovers, E., Assefa, Z., Asrat, A., Pearson, O.M., Bahain, J.-J., Lam, Y.M., 2014. After the Dispersal: cultural change or continuity in the Late MSA/Early LSA of southeastern Ethiopia? The site of Goda Buticha, Dire Dawa area. Quaternary International 343, 117-135.

Rebollo, N.R., Weiner, S., Brock, F., Meignen, L., Goldberg, P., Belfer-Cohen, A., Bar-Yosef, O., Boaretto, E., 2011. New radiocarbon dating of the transition from the Middle to the Upper Paleolithic in Kebara Cave, Israel. Journal of Archaeological Science 38, 2424-2433.

Reimer, P.J., Bard, E., Bayliss, A., Beck, J.W., Blackwell, P.G., Bronk Ramsey, C., Buck, C.E., Cheng, H., Edwards, R.L., Friedrich, M., Grootes, P.M., Guilderson, T.P., Haflidason, H., Hajdas, I., Hatté, C., Heaton, T.J., Hoffmann, D.L., Hogg, A.G., Hughen, K.A., Kaiser, K.F., Kromer, B., Manning, S.W., Niu, M., Reimer, R.W., Richards, D.A., Scott, E.M., Southon, J.R., Staff, R.A., Turney, C.S.M., van der Plicht, J., 2013. IntCal13 and Marine13 radiocarbon age calibration curves 0-50,000 years cal BP. Radiocarbon 55(4), 1869-1887.

Rethemeyer, J., Fülöp, R.-H., Höfle, S., Wacker, L., Heinze, S., Hajdas, I., Patt, U., König, S., Stapper, B., Dewald, A. 2013. Status report on sample preparation facilities for 14C analysis at the new Cologne AMS center. Nuclear Instruments and Methods in Physics Research B 294, $168-172$.

Rosso, D.E., d' Errico, F., Zilhão, J. 2014. Stratigraphic and spatial distribution of ochre and ochre processing tools at Porc-Epic Cave, Dire Dawa, Ethiopia. Quaternary International 343, 85-99.

Santos, G.M., Bird, M.I., Parenti, F., Fifield, L.K., Guidon, N., Hausladen, P.A., 2003. The controversial antiquity of the peopling of the Americas: a review of the chronology of the lowest occupation layer in the Pedra Furada Rock Shelter, Piauí, Brazil. Quaternary Science Reviews $22,2303-2310$.

Schmidt, C., Kindermann, K., Van Peer, P., Bubenzer, O. 2015. Multi-emission luminescence dating of heated chert from the Middle Stone Age sequence at Sodmein Cave (Red Sea Mountains, Egypt). Journal of Archaeological Science 63, 94-103. 
Shea, J.J. 2008. Transitions or turnovers? Climatically-forced extinctions of Homo sapiens and Neanderthals in the east Mediterranean Levant. Quaternary Science Reviews 27, 2253-2270.

Soares, P., Alshamali, F., Pereira, J., Fernandes, V., Silva, N.M., Alfonso, C., Costa, M., Misilova, E., Macaulay, V., Richards, M., Cerny, V, Pereira, L. 2011. The expansion of mtDNA Haplogroup L3 within and out of Africa. Molecular Biology \& Evolution, doi: 10.1093/molbev/msr245

Soares, P., Rito, T., Pereira, L., Richards, M.B. 2016. A genetic perspective on African prehistory. In: Jones, S.C., Stewart, B.A., (Eds.), Africa from MIS 6-2: Population Dynamics and Paleoenvironments. Springer, Dordrecht, pp. 383-405.

Sellet, F. 1995. Levallois or not Levallois: Does it really matter? Learning from an African case. In: Dibble, H.L. \& Bar-Yosef, O. (Eds.), The Definition and Interpretation of Levallois Technology. Monographs in World Archaeology No. 23, Prehistory Press, Madison Wisconsin, pp. 25-39.

Stewart, B.A., Jones, S.C. 2016. Africa from MIS 6-2: The fluorescence of modern humans. In: Jones, S.C., Stewart, B.A., (Eds.), Africa from MIS 6-2: Population Dynamics and Paleoenvironments. Springer, Dordrecht, pp. 1-22.

Stewart, J.R., Stringer, C.B. 2012. Human evolution out of Africa: the role of refugia and climate change. Science 335, 1317-1321.

Stokes, S., Bailey, R. 2002. Optical dating of Nazlet Safaha and Nazlet Khater. In: Vermeersch, P. (Ed.), Palaeolithic Quarrying Sites in Upper and Middle Egypt. Leuven University Press, Leuven, pp. 349-350.

Stuiver, M., Polach, H., 1977. Reporting of 14C data. Radiocarbon 19, 355-363.

Suess, H.E. 1967. Bristlecone pine calibration of the radiocarbon time scale from $4100 \mathrm{BC}$ to 1500 BC. In IAEA staff (Eds.) Radioactive Dating and Low-Level Counting: Proceedings of a Symposium Organized by the International Atomic Energy Agency (IAEA) in Cooperation with the Joint Commission on Applied Radioactivity (ICSU), Monaco, 2-10 March 1967.

International Atomic Energy Agency (IAEA), Vienna, 143-152.

Taylor, R.E., Bar-Yosef O. 2014. Radiocarbon Dating: An Archaeological Perspective. $2^{\text {nd }}$ Edition. Walnut Creek: Left Coast Press.

Turney, C.S.M., Bird, M.I., Fifield, L.K., Roberts, R.G., Smith, M.A., Dortch, C.E., Grün, R., Lawson, E., Ayliffe, L.K., Miller, G.H., Dortch, J., Cresswell, R.G. 2001. Early human occupation at Devil's Lair, southwestern Australia 50,000 years ago. Quaternary Research 55, 313. 
Van Peer, P. 1991. New observations about the Nile Valley Middle Palaeolithic: Sahafa Method and lateralization of Levallois flakes. Paléorient 17/2, 135-142.

Van Peer, P. 2016. Technological systems, population dynamics, and historical process in the MSA of Northern Africa. In: Jones, S.C., Stewart, B.A., (Eds.), Africa from MIS 6-2: Population Dynamics and Paleoenvironments. Springer, Dordrecht, pp. 147-160.

Van Peer, P., Vermeersch, P.M. 2000. The Nubian complex and the dispersal of modern humans in North Africa. In: Krzyzaniak, L., Kroeper, K. (Eds.), Recent Research into the Stone Age of Northeastern Africa. Studies in African Archaeology 7, Poznan Archaeological Museum, pp. 4760 .

Van Peer, P., Vermeersch, R M., \& Paulissen, E. 2010. Chert quarrying, lithic technology and a modern human burial at the palaeolithic site of Taramsa 1, Upper Egypt. Egyptian Prehistory Monographs. Leuven University Press, Leuven.

Van Peer, P., Vermeersch, P.M., Moeyersons, J. 1996. Palaeolithic stratigraphy of Sodmein Cave (Red Sea Mountains, Egypt). Seminar on Geo-archaeology in Tropical and Mediterranean Regions. Royal Academy of Overseas Sciences, Brussels. Geo-Eco-Trop. 20(1-4), 61-71.

Vermeersch, P.M. 2002. Geomorphology of the Nazlet Khater area. In: Vermeersch, P. (Ed.), Palaeolithic Quarrying Sites in Upper and Middle Egypt. Leuven University Press, Leuven, pp. 21-25.

Vermeersch, P.M., Paulissen, E., Vanderbeken, T. 2002. Nazlet Khater 4: an Upper Palaeolithic underground chert mine. In: Vermeersch, P. (Ed.), Palaeolithic Quarrying Sites in Upper and Middle Egypt. Leuven University Press, Leuven, pp. 211-271.

Wang, H., Hackley, K.C., Panno, S.V., Coleman, D.D., Liu, J.C.-L., Brown, J., 2003. Pyrolysis combustion ${ }^{14} \mathrm{C}$ dating of soil organic matter. Quaternary Research 60, 348-355.

Wang, H., Ambrose, S.H., Hedman, K.M., Emerson, T.E., 2010. AMS ${ }^{14}$ C dating of human bones using sequential pyrolysis and combustion of collagen. Radiocarbon 52, 157-163.

Warren, A., 2010. Preliminary Characterization and Provenance of Obsidian Artifacts from Ethiopian Archaeological Sites using Portable X-Ray Fluorescence. Unpublished BA thesis, University of Florida, Gainesville.

Wendorf, F., Schild, R., Herbert, H., 1979. A new radiocarbon chronology for prehistoric sites in Nubia. Journal of Field Archaeology 6(2), 219-223.

Weninger, B., Jöris, O., 2008. A ${ }^{14} \mathrm{C}$ age calibration curve for the last 60 ka: the Greenland-Hulu U/Th timescale and its impact on understanding the Middle to Upper Paleolithic transition in Western Eurasia. Journal of Human Evolution 55, 772-781. 
Whittle, A., Bayliss, A., \& Healy, F. 2008. The timing and tempo of change: examples from the fourth millennium cal. BC in Southern England. Cambridge Archaeological Journal 18(1), 6570, doi:10.1017/S0959774308000061.

Wurz, S., Van Peer, P. 2012. Out of Africa, the Nile Valley and the Northern Route. South African Archaeological Bulletin 67(196), 168-179. 


\section{Figures and Tables}

\subsection{List of Tables in Main Material}

Table 1. Representation of stone artifacts in assemblages analyzed so far from late Pleistocene excavations in Mochena Borago's Block Excavation Area (BXA).

Table 2. Radiocarbon age determinations from Illinois Geological Survey (ISGS) and University of Cologne (COL). On the right side of the table, columns denote inclusion in various stages of modeling attempts: <49 ka (third-last column), allowing the initial model to succeed (second-last column), and meeting the convergence $(\mathrm{C})$ and probability $(\mathrm{P})$ criteria for inclusion in the final model (last column).

Table 3. Output data file for the final run of the "clean" model (with the outliers excluded).

Table 4. Comparison of age ranges for major stratigraphic groups in the BXA. Rows with grey fill represent hiati in rockshelter use during major volcanic events. Weighted means (after Brandt et al. 2012) are presented on the left-hand three columns. Start and end dates for major stratigraphic groups based on the "clean" Bayesian model (outliers excluded) appear on the right side of the table. All dates are Cal BP.

\subsection{List of Figures}

Figure 1. Regional map with sites listed in text. 1 - Gud Gud; 2 - Midhishi; 3 - Laas Geel; 4 Porc Epic; 5 - Goda Buticha; 6 - Main Ethiopian Rift site area; 7 - Mochena Borago; 8 - Omo Kibish sites; 9 - Sodmein; 10 - Nazlet Khater (NK4); 11 - Nazlet Safaha; 12 - Taramsa 1; 13 Khormusan Site 1017.

Figure 2. Plan view of Mochena Borago Rockshelter.

Figure 3. Profile of NW wall of excavation unit H9 in the Block Excavation Area. Major stratigraphic groups are outlined.

Figure 4. Plotted probability curves $(95.4 \%)$ for the initial model run with 31 dates included. Pale grey curves show unmodeled probability curves for calibrations; dark grey curves show modeled probability curves for calibrations. Outliers are marked with an $\mathrm{X}$ on the right side.

Figure 5. Plotted probability curves $(95.4 \%)$ for the clean model run (outliers excluded)

\subsection{List of Tables in Supplementary Material}

Table A. Unmodeled calibrations using CalPal and IntCal. CalPal calibrations have the format $1234 \pm 56$ BP. IntCal calibrations are presented as an age range: "IntCal BP from" denotes the start of the calibrated age range (e.g., 1178 BP), and "IntCal BP to" denotes the end of that age range (e.g., $1290 \mathrm{BP}$ ).

Table B. Code for the OxCal run of the initial model (with the outliers included).

Table C. Code for the OxCal run of the "clean" model (with the outliers excluded).

Table D. Output file from the initial model run (with the outliers included). 
Table 1

\begin{tabular}{|c|c|c|c|c|}
\hline $\begin{array}{l}\text { ARTIFACT PERCENTAGE BY } \\
\text { STRATIGRAPHIC GROUP }\end{array}$ & $\begin{array}{l}\text { Lower } \mathrm{T} \\
\mathrm{N}=1059\end{array}$ & $\begin{array}{l}\text { Upper T } \\
\mathrm{N}=1953\end{array}$ & $\begin{array}{l}\text { S Group } \\
\mathrm{N}=3245\end{array}$ & $\begin{array}{l}\mathrm{R} \text { Group } \\
{ }^{*} \mathrm{~N}=1000\end{array}$ \\
\hline Obsidian & 94 & 97 & 99 & 99 \\
\hline Non-Obsidian Volcanics & 3 & 2 & $<1$ & $<1$ \\
\hline Chert & 3 & 1 & $<1$ & $<1$ \\
\hline RAW MATERIAL & $n=1059$ & $n=1953$ & $n=3245$ & $n=1000$ \\
\hline Fresh & 99 & 98 & 86 & 34 \\
\hline Damaged & 1 & 2 & 14 & 66 \\
\hline DAMAGED & $n=1059$ & $n=1953$ & $n=3245$ & $n=1000$ \\
\hline$\%$ & 94 & 97 & 99 & 99 \\
\hline Levallois (includes Nubian) & 18 & 11 & 4 & 8 \\
\hline Discoidal & $* *$ & $* *$ & $\mathrm{x}$ & 2 \\
\hline Bipolar & $* *$ & $* *$ & 26 & 10 \\
\hline Irregular & $* *$ & $* *$ & 22 & 9 \\
\hline CORES & $n=17$ & $n=18$ & $n=27$ & $n=63$ \\
\hline$\%$ & $2 \%$ & $1 \%$ & $1 \%$ & $6 \%$ \\
\hline Angular Waste & $<1$ & 3 & 5 & 15 \\
\hline Flakes/Blades & 17 & 20 & 26 & 75 \\
\hline Fragments & 81 & 77 & 67 & $\mathrm{x}$ \\
\hline Levallois & $<1$ & $<1$ & $\mathrm{x}$ & $<1$ \\
\hline Levallois Points/Frags & $<1$ & $x$ & $<1$ & $x$ \\
\hline CTF & $<1$ & $<1$ & 2 & 8 \\
\hline Burin Spalls & $\mathrm{x}$ & $\mathrm{x}$ & 1 & 1 \\
\hline DEBRIS & $n=1006$ & $n=1826$ & $n=3061$ & $n=771$ \\
\hline$\%$ & $95 \%$ & 93.5 & $94 \%$ & $77 \%$ \\
\hline Nibbled ("Utilized") & 47 & 79 & 31 & 34 \\
\hline Modified & 53 & 21 & 69 & 66 \\
\hline UNSHAPED TOOLS & $\mathrm{n}=15$ & $n=56$ & $n=89$ & $n=93$ \\
\hline$\%$ & $1 \%$ & $3 \%$ & $3 \%$ & 9.3 \\
\hline Backed & $* *$ & 21 & 35 & 20 \\
\hline Burins & $<1$ & 6 & $x$ & $* * * 30$ \\
\hline Drills/awls/becs & $x$ & 4 & 3 & 1 \\
\hline Notches & $x$ & 2 & $x$ & 3 \\
\hline Points & 62 & 43 & 15 & 20 \\
\hline Scrapers & 33 & 21 & 44 & 25 \\
\hline Irregular/Frag & $x$ & 4 & $x$ & $\mathrm{x}$ \\
\hline SHAPED TOOLS & $n=21$ & $n=53$ & $n=68$ & $n=76$ \\
\hline$\%$ & 2 & $3 \%$ & $2 \%$ & $2 \%$ \\
\hline
\end{tabular}




\begin{tabular}{|c|c|}
\hline Sample \# & Bag \# \\
\hline SWAP08-11 & 3424 ISGS-A1227 \\
\hline SWAP08-07 & 2141 ISGS-A1063 \\
\hline SWAP08-08 & 2237 ISGS-A1064 \\
\hline SWAP07-03 & 2200 ISGS-A1024 \\
\hline SWAP08-10 & 3834 ISGS-A1226 \\
\hline SWAP08-12 & 2804 ISGS-A1228 \\
\hline SWAP07-05 & 2596 ISGS-A1015 \\
\hline SWAP10-01 & 11105 COL2367.1.1 \\
\hline SWAP14-11 & 11830 COL2368.1.1 \\
\hline SWAP08-05 & 3346 ISGS-A1062 \\
\hline SWAP07-06 & 3334 ISGS-A1013 \\
\hline SWAP08-09 & 2248 ISGS-A1225 \\
\hline SWAP14-13 & 14808 COL2370.1.1 \\
\hline SWAP14-12 & 14835 COL2369.1.1 \\
\hline SWAP07-07 & 4039 ISGS-A1014 \\
\hline SWAP08-04 & 4002 ISGS-A1057 \\
\hline SWAP12-02 & 33228-A COL1833.1.1 \\
\hline SWAP12-01 & 33228-B ISGS-A2261 \\
\hline SWAP08-03 & 2037 ISGS-A1060 \\
\hline SWAP07-09 & 2105 ISGS-A1019 \\
\hline SWAP14-04 & 17058 COL2333.1.1 \\
\hline SWAP14-05 & 17082 COL2334.1.1 \\
\hline SWAP08-02 & 2109 ISGS-A1059 \\
\hline SWAP07-11 & 2117 ISGS-A1017 \\
\hline SWAP12-04 & 33380-A COL1834.1.1 \\
\hline SWAP12-03 & 33380-B ISGS-A2262 \\
\hline SWAP12-05 & 33404 COL1835.1.1 \\
\hline SWAP07-12 & 3112 ISGS-A1018 \\
\hline SWAP14-08 & 30456-B COL2337.1.1 \\
\hline SWAP14-07 & 33458 COL2336.1.1 \\
\hline SWAP14-01 & 29996 ISGS-A3129 \\
\hline SWAP08-01 & 3135 ISGS-A1058 \\
\hline SWAP07-13 & 3123 ISGS-A1025 \\
\hline SWAP14-09 & 36618 COL2720.2.1 \\
\hline SWAP14-03 & 36654 ISGS-A3113 \\
\hline SWAP14-06 & 33706 COL2335.1.1 \\
\hline SWAP14-02 & 37317 ISGS-A3131 \\
\hline
\end{tabular}

Excavation

\section{Unit Major strat Minor strat}

Unit Level group

G9

H9

H9

H9

G9

H9

H9

G9

G9

H9

$\mathrm{H} 9$

G10

G9

G9

H9

H9

G9 NE

G9 NE

G10

G10

H9 NE

H9 NE

G10

G10

G9 NE

G9 NE

G9 NE

G10

G9 SE

G9 NE

H9 NW

G10

G10

H9

H9 NW

G9 NE

H9 SW

$\begin{array}{cl}4 & \text { Upper R } \\ 15 & \text { Upper R } \\ 15 & \text { Upper R } \\ 15 & \text { Upper R } \\ 5 & \text { Upper R } \\ 18 & \text { Upper R } \\ 18 & \text { Upper R } \\ 11 & \text { Lower R } \\ 12 & \text { Lower R } \\ 19 & \text { Lower R } \\ 19 & \text { Lower R } \\ & \text { YBS }\end{array}$

15 YBS

15 YBS

26 S-group

26 S-group

52 S-group

52 S-group

17 YBT

17 YBT

50 YBT

53 YBT

18 Transition

19 Upper T

66 Upper T

66 Upper T

68 Upper $\mathrm{T}$

23 Upper $T$

67 Upper T

70 Upper T

104 Upper T

24 Upper T

25 Lower T

108 Lower T

109 Lower T

75 Lower T

110 Lower $\mathrm{T}$ subunit

$\begin{array}{ll}R C A & 2213.756\end{array}$

RCA

RCA

RCA

RCA

RCA

RGCM

RGCB

RGCA

RGCA

YBS

YBS

YBS

VDBS

VDBS

$A B A$

ABA

YBT main

YBT main

YBT-SCS

YBT-SCS

YBT/DCC

DCC

ADD

ADD

ADD

DCC

ACY

ADD

AEC

DCC

CTT

AED

AED

ADM

AED

2213.743

2213.740

2213.709

2213.657

2213.630

2213.663

2213.647

2213.624

2213.621

2213.527

2213.518

2213.516

2213.375

2213.365

2213.148

2213.148

2213.185

2213.116

2213.028

2212.992

2213.008

2212.975

2212.913

2212.913

2212.880

2212.840

2212.812

2212.812

2212.767

2212.743

2212.780

2212.718

2212.679

2212.664

2212.639
14C bp

$37200 \pm 560$

$36120 \pm 590$

$33370 \pm 420$

$35010 \pm 270$

$34360 \pm 400$

$36900 \pm 540$

$37930 \pm 370$

$36108 \pm 220$

$37861 \pm 247$

$40500 \pm 1000$

$41580 \pm 590$

$38750 \pm 680$

$39914 \pm 276$

$37847 \pm 246$

$39200 \pm 440$

$44000 \pm 1600$

$>49000$

$45470 \pm 2180$

$36960 \pm 650$

$41830 \pm 600$

$42347 \pm 337$

$42842 \pm 362$

$47700 \pm 2500$

$42400 \pm 650$

$43284 \pm 1058$

$40210 \pm 980$

$>49000$

$39920 \pm 480$

$45341 \pm 425$

$45182 \pm 427$

$24270 \pm 150$

$26400 \pm 180$

$48850 \pm 1420$

$33891 \pm 295$

$25720 \pm 140$

$48102 \pm 536$

$35720 \pm 470$
Initial

Clean

$d^{13} \mathrm{C}<49 \mathrm{k}$ ? model model

-21.1 Yes Yes Yes

-24.8 Yes Yes Yes

-22.2 Yes Yes Yes

-23.7 Yes Yes Yes

-23.6 Yes Yes Yes

-25.5 Yes Yes Yes

-23.3 Yes Yes Yes

-27.2 Yes Yes Yes

-26.8 Yes Yes Yes

-25.2 Yes Yes

-22.9 Yes Yes

-25.1 Yes Yes Yes

-23.8 Yes Yes Yes

-27.6 Yes Yes

-28.9 Yes Yes

-23.9 Yes Yes

$-28.5$

*** Yes Yes

*** Yes Yes

-26.8 Yes Yes Yes

-24.7 Yes Yes Yes

-21.8 Yes Yes Yes

-23.3 Yes Yes Yes

-23.7 Yes Yes Yes

-25.9 Yes Yes Yes

*** Yes Yes Yes

$-25.6$

-22.2 Yes

-23.4 Yes

-22.6 Yes

-20.7 Yes

-24.3 Yes

-24.2 Yes

-23.1 Yes

-21.4 Yes

-16.5 Yes

-23.1 Yes
Yes

Yes Yes

Yes Yes

Yes

Yes

Yes

Yes

Yes 


\begin{tabular}{|c|c|c|c|c|c|c|c|c|c|c|c|c|c|}
\hline \multirow[t]{2}{*}{ Name } & \multicolumn{5}{|c|}{ Unmodelled (BP) } & \multicolumn{5}{|c|}{ Modelled (BP) } & \multicolumn{3}{|c|}{ Diagnostic criteria } \\
\hline & \multirow[t]{3}{*}{ from } & to & $\%$ & $\mathrm{mu}$ & sigma & from to & \multirow{2}{*}{ to 36557} & \multicolumn{2}{|c|}{$\% \quad \mathrm{mu}$} & sigma & \multirow[t]{2}{*}{ A $\quad$ C } & \multicolumn{2}{|l|}{ C $\quad P$} \\
\hline Boundary R.End & & & & & & 39623 & & 95.4 & 38109 & 744 & & 94.2 & \\
\hline Span R & & & & & & 2426 & 4983 & 95.4 & 3751 & 622 & & 99 & \\
\hline R_Date SWAP08-11 & 42544 & 40729 & 95.4 & 41668 & 445 & 42415 & 40710 & 95.4 & 41615 & 441 & 104.6 & 99.4 & 96.1 \\
\hline R_Date SWAP08-07 & 41860 & 39579 & 95.4 & 40731 & 582 & 41870 & 39566 & 95.4 & 40732 & 589 & 101.2 & 99.3 & 95.9 \\
\hline R_Date SWAP08-08 & 38637 & 36475 & 95.4 & 37609 & 583 & 40864 & 37002 & 95.4 & 38615 & 887 & 64.6 & 98.5 & 84.1 \\
\hline R_Date SWAP07-03 & 40206 & 38870 & 95.4 & 39547 & 341 & 40281 & 38845 & 95.4 & 39585 & 402 & 100.3 & 99.4 & 95.3 \\
\hline R_Date SWAP08-10 & 39907 & 38035 & 95.4 & 38927 & 458 & 40088 & 38163 & 95.4 & 39087 & 528 & 98.2 & 99.4 & 94.6 \\
\hline R_Date SWAP08-12 & 42299 & 40444 & 95.4 & 41422 & 463 & 42256 & 40450 & 95.4 & 41400 & 466 & 102.5 & 99.5 & 96.1 \\
\hline R_Date SWAP07-05 & 42718 & 41684 & 95.4 & 42199 & 257 & 42583 & 41610 & 95.4 & 42079 & 313 & 103.4 & 99.5 & 95.6 \\
\hline R_Date SWAP10-01 & 41301 & 40216 & 95.4 & 40761 & 279 & 41325 & 40194 & 95.4 & 40761 & 304 & 100.9 & 99.5 & 96 \\
\hline R_Date SWAP14-11 & 42530 & 41775 & 95.4 & 42151 & 188 & 42486 & 41710 & 95.4 & 42069 & 340 & 102.1 & 99.6 & 95.4 \\
\hline \multicolumn{14}{|l|}{ Phase $R$} \\
\hline Boundary R.Start & & & & & & 43134 & 41972 & 95.4 & 42498 & 296 & & 99.9 & \\
\hline Boundary YBS.End & & & & & & 43746 & 42291 & 95.4 & 43028 & 372 & & 99.7 & \\
\hline Span YBS & & & & & & 0 & 871 & 95.4 & 274 & 276 & & 99.9 & \\
\hline R_Date SWAP08-09 & 43970 & 41851 & 95.4 & 42820 & 524 & 44061 & 42581 & 95.4 & 43312 & 369 & 73.6 & 99.8 & 95.8 \\
\hline R_Date SWAP14-13 & 44168 & 43021 & 95.4 & 43566 & 293 & 44038 & 42977 & 95.4 & 43477 & 269 & 105 & 99.9 & 96.5 \\
\hline Phase YBS & & & & & & & & & & & & & \\
\hline Boundary YBS.Start & & & & & & 44935 & 43061 & 95.4 & 43884 & 486 & & 99.6 & \\
\hline Boundary S.End & & & & & & 45879 & 43885 & 95.4 & 44973 & 510 & & 99.3 & \\
\hline Span S & & & & & & 0 & 578 & 95.4 & 155 & 191 & & 100 & \\
\hline R_Date SWAP08-04. & $\ldots$ & 45289 & 95.4 & 47460 & 1316 & 46003 & 44512 & 95.4 & 45293 & 375 & 47 & 99.9 & 94.4 \\
\hline R_Date SWAP12-01 . & $\ldots$ & 45803 & 95.4 & 48048 & 1244 & 46010 & 44522 & 95.4 & 45299 & 375 & 18.2 & 99.8 & 92 \\
\hline Phase S & & & & & & & & & & & & & \\
\hline Boundary S.Start & & & & & & 46136 & 44790 & 95.4 & 45493 & 336 & & 99.8 & \\
\hline Boundary YBT.End & & & & & & 46293 & 45210 & 95.4 & 45754 & 267 & & 99.7 & \\
\hline Span YBT & & & & & & 0 & 810 & 95.4 & 244 & 270 & & 99.9 & \\
\hline R_Date SWAP07-09 & 46382 & 44196 & 95.4 & 45261 & 544 & 46441 & 45379 & 95.4 & 45902 & 263 & 65.2 & 99.9 & 95.7 \\
\hline R_Date SWAP14-04 & 46305 & 44995 & 95.4 & 45642 & 327 & 46387 & 45422 & 95.4 & 45899 & 241 & 92.7 & 99.9 & 96.4 \\
\hline R_Date SWAP14-05 & 46859 & 45344 & 95.4 & 46075 & 380 & 46463 & 45472 & 95.4 & 45953 & 248 & 118.7 & 99.9 & 96.9 \\
\hline R_Date SWAP08-02 & 56957 & 43513 & 95.4 & 49320 & 3455 & 46658 & 45422 & 95.4 & 46001 & 311 & 106.3 & 99.9 & 89.3 \\
\hline Phase YBT & & & & & & & & & & & & & \\
\hline Boundary YBT.Start & & & & & & 46939 & 45523 & 95.4 & 46155 & 360 & & 99.5 & \\
\hline Boundary UpperT.End & & & & & & 47965 & 45735 & 95.4 & 46714 & 610 & & 99.5 & \\
\hline Span UpperT & & & & & & 0 & 2504 & 95.4 & 1268 & 750 & & 99.5 & \\
\hline R_Date SWAP07-11 & 47117 & 44585 & 95.4 & 45792 & 632 & 48287 & 45983 & 95.4 & 47094 & 631 & 30.9 & 99.5 & 90.4 \\
\hline R_Date SWAP12-03 & 45726 & 42489 & 95.4 & 44034 & 848 & 48332 & 45986 & 95.4 & 47117 & 637 & 3.1 & 99.5 & 78.8 \\
\hline R_Date SWAP12-04 & 49215 & 44881 & 95.4 & 46860 & 1104 & 48332 & 45986 & 95.4 & 47117 & 637 & 113.8 & 99.5 & 96.1 \\
\hline Combined $12-3,12-4$ & 46942 & 44187 & 95.4 & 45496 & 682 & 48332 & 45986 & 95.4 & 47117 & 637 & & 99.5 & \\
\hline R_Date SWAP14-08 & 49882 & 47740 & 95.4 & 48777 & 551 & 49035 & 47083 & 95.4 & 48041 & 509 & 67.3 & 99.6 & 93 \\
\hline R_Date SWAP14-07 & 49751 & 47497 & 95.4 & 48605 & 570 & 48968 & 47055 & 95.4 & 47991 & 495 & 80.8 & 99.6 & 94.2 \\
\hline Phase UpperT & & & & & & & & & & & & & \\
\hline Boundary UpperT.Star & & & & & & 49445 & 47375 & 95.4 & 48401 & 550 & & 99.5 & \\
\hline Boundary LowerT.End & & & & & & 49853 & 47836 & 95.4 & 48880 & 578 & & 99.1 & \\
\hline R_Date SWAP07-13 & 52505 & 46348 & 95.4 & 49270 & 1568 & 50005 & 48973 & 95.4 & 49701 & 561 & 123 & 97.4 & 95.6 \\
\hline R_Date SWAP14-06 & 49256 & 47093 & 95.4 & 48156 & 543 & 50017 & 49245 & 95.4 & 50226 & 1981 & 2.3 & 96.6 & 92.7 \\
\hline Phase LowerT & & & & & & & & & & & & & \\
\hline Sequence BXA & & & & & & & & & & & & & \\
\hline$U(0,4)$ & $3.99 E-17$ & 4 & 95.4 & 2 & 1.1431 & $5.38 \mathrm{E}-17$ & 3.94 & 95.5 & 2.33465 & 1.1455 & 100 & 82.2 & \\
\hline $\mathrm{T}(5)$ & -2.65 & 2.65 & 95.4 & $-2.27 \mathrm{E}-08$ & 1.2908 & & & & 0.32978 & 1.842 & & 98.3 & \\
\hline Outlier_Model Genera & & & & & & -3467 & 4628 & 95.4 & 544 & 2136 & & 99.5 & \\
\hline
\end{tabular}


Table 4. Comparison of age ranges for major stratigraphic groups in the BXA.

Rows with grey fill represent hiati in rockshelter use during major volcanic events.

Weighted means (after Brandt et al. 2012) are presented on the left-hand three columns

Start and end dates for major stratigraphic groups based on the "clean" Bayesian model (outliers excluded) appear on the right side of the table. All dates are Cal BP.

\begin{tabular}{|c|c|c|c|c|c|c|c|c|}
\hline $\begin{array}{l}{ }^{14} \mathrm{C} \text { dates } \\
\text { available } \\
\text { in } 2012(\#)\end{array}$ & $\begin{array}{l}\text { Weighted } \\
\text { mean }(1 \sigma)\end{array}$ & $\begin{array}{l}\text { Weighte } \\
\text { age ran } \\
\text { Start }\end{array}$ & $\begin{array}{l}\text { d mean } \\
\text { ge: }(2 \sigma) \\
\text { End }\end{array}$ & $\begin{array}{l}\text { Strati- } \\
\text { graphic } \\
\text { Group }\end{array}$ & $\begin{array}{l}{ }^{14} \mathrm{C} \mathrm{c} \\
\text { ava } \\
\text { Tota }\end{array}$ & $\begin{array}{l}\text { es now } \\
\text { ble }(\#) \text { : } \\
\text { In clean } \\
\text { model }\end{array}$ & $\begin{array}{l}\text { Bayesian model } \\
\text { BP age range for } \\
\text { start of phase }(2 \sigma)\end{array}$ & $\begin{array}{l}\text { Bayesian model } \\
\text { BP age range for } \\
\text { end of phase }(2 \sigma)\end{array}$ \\
\hline 11 & $41,159 \pm 783$ & 42,700 & 39,600 & R-Group & 11 & 9 & $43,134-41,972$ & $39,623-36,557$ \\
\hline 1 & $43,121 \pm 692$ & 44,500 & 41,800 & YBS & 3 & 2 & $44,935-43,061$ & $43,746-42,291$ \\
\hline 3 & $43,480 \pm 443$ & 44,300 & 42,600 & S-Group & 4 & 2 & $46,136-44,790$ & $45,879-43,885$ \\
\hline 3 & $43,403 \pm 1213$ & 45,800 & 41,000 & YBT & 5 & 4 & $46,939-45,523$ & $46,293-45,210$ \\
\hline 3 & $45,164 \pm 982$ & 47,100 & 43,200 & Upper T & 9 & 5 & $49,445-47,375$ & $47,965-45,735$ \\
\hline 1 & $53,224 \pm 2662$ & 58,400 & 48,000 & Lower $\mathrm{T}$ & 5 & 2 & No model age & $49,853-47,836$ \\
\hline
\end{tabular}




\section{Figure}

Click here to download high resolution image

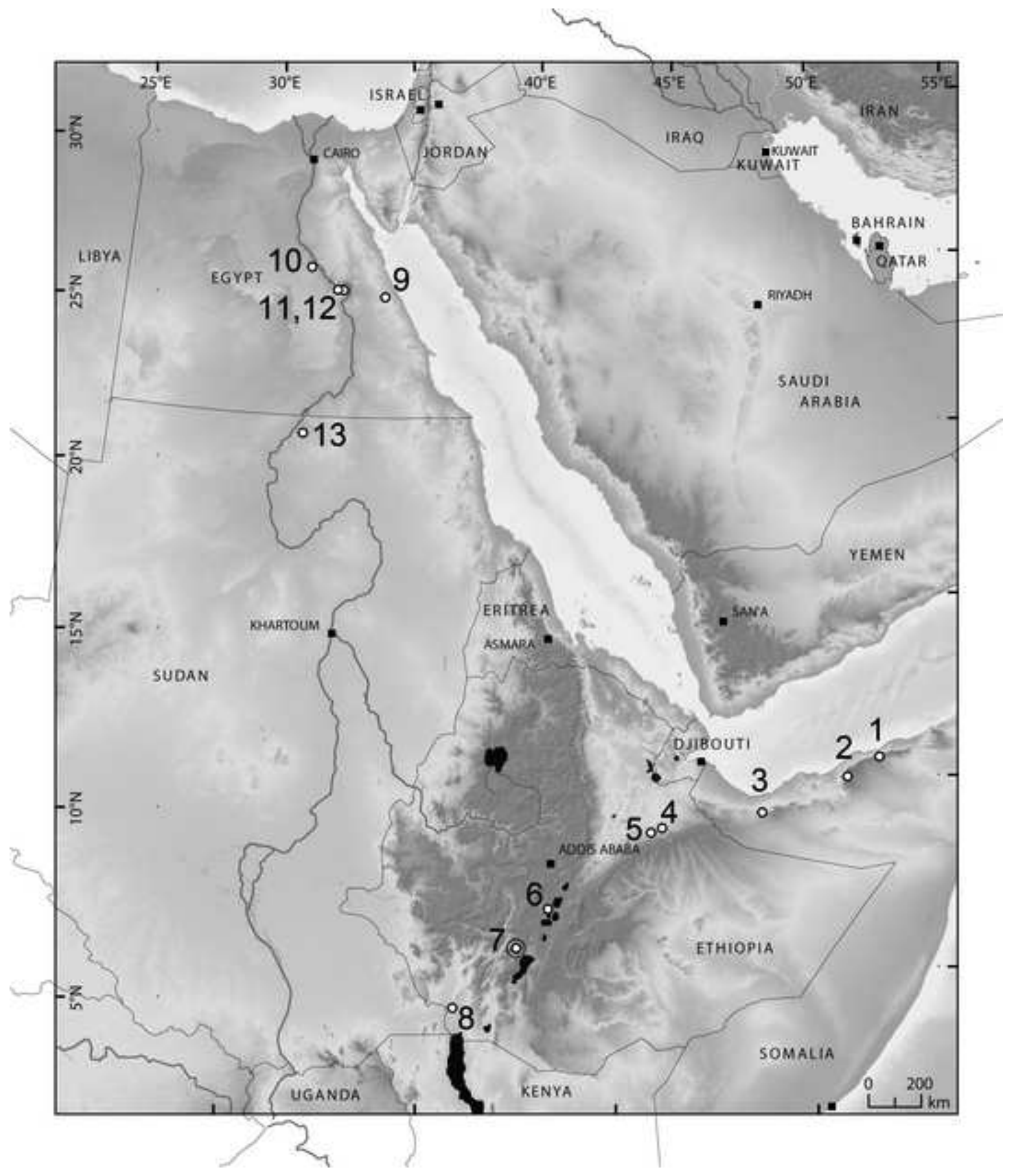




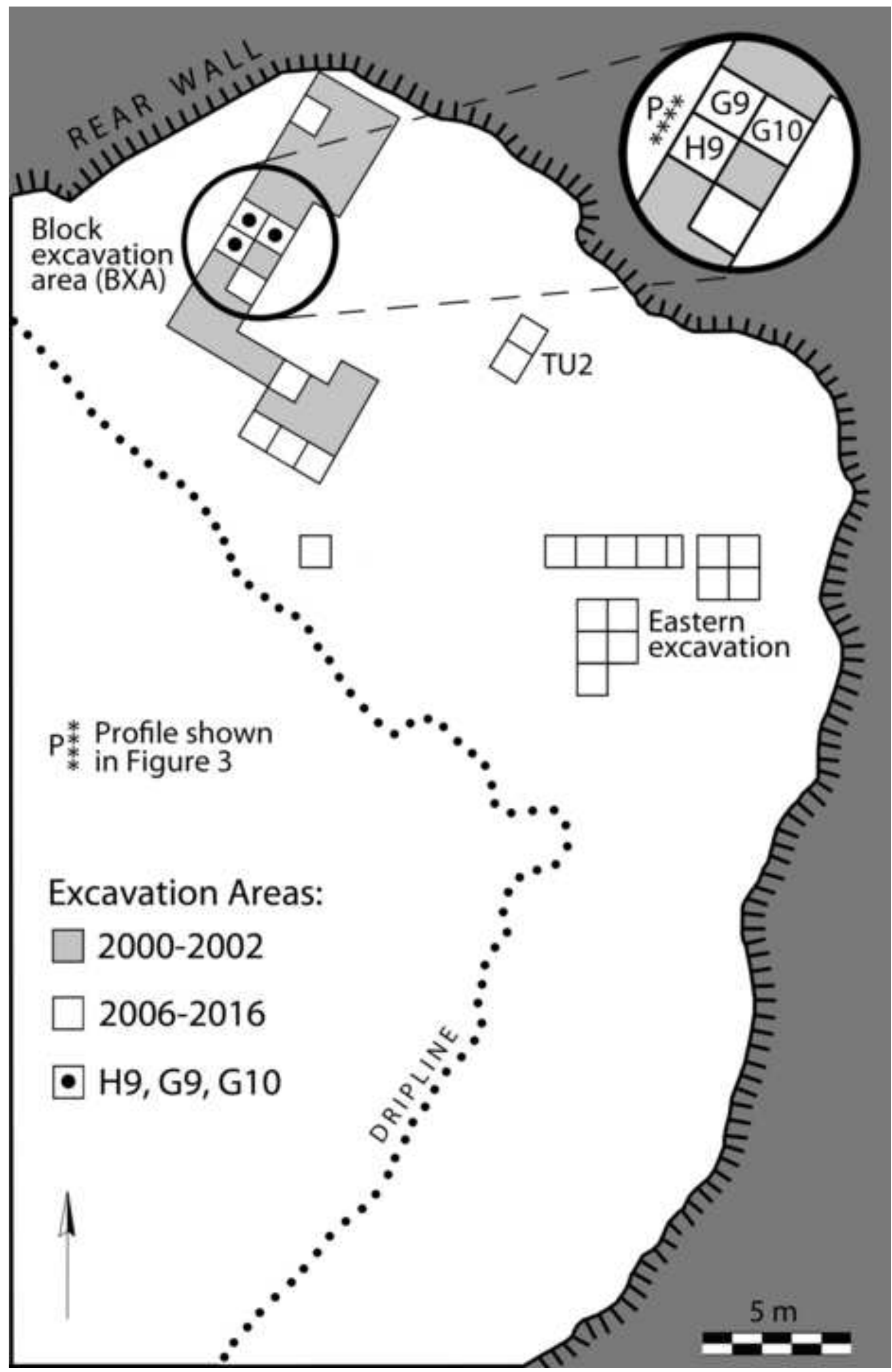




\section{Click here to download high resolution image}

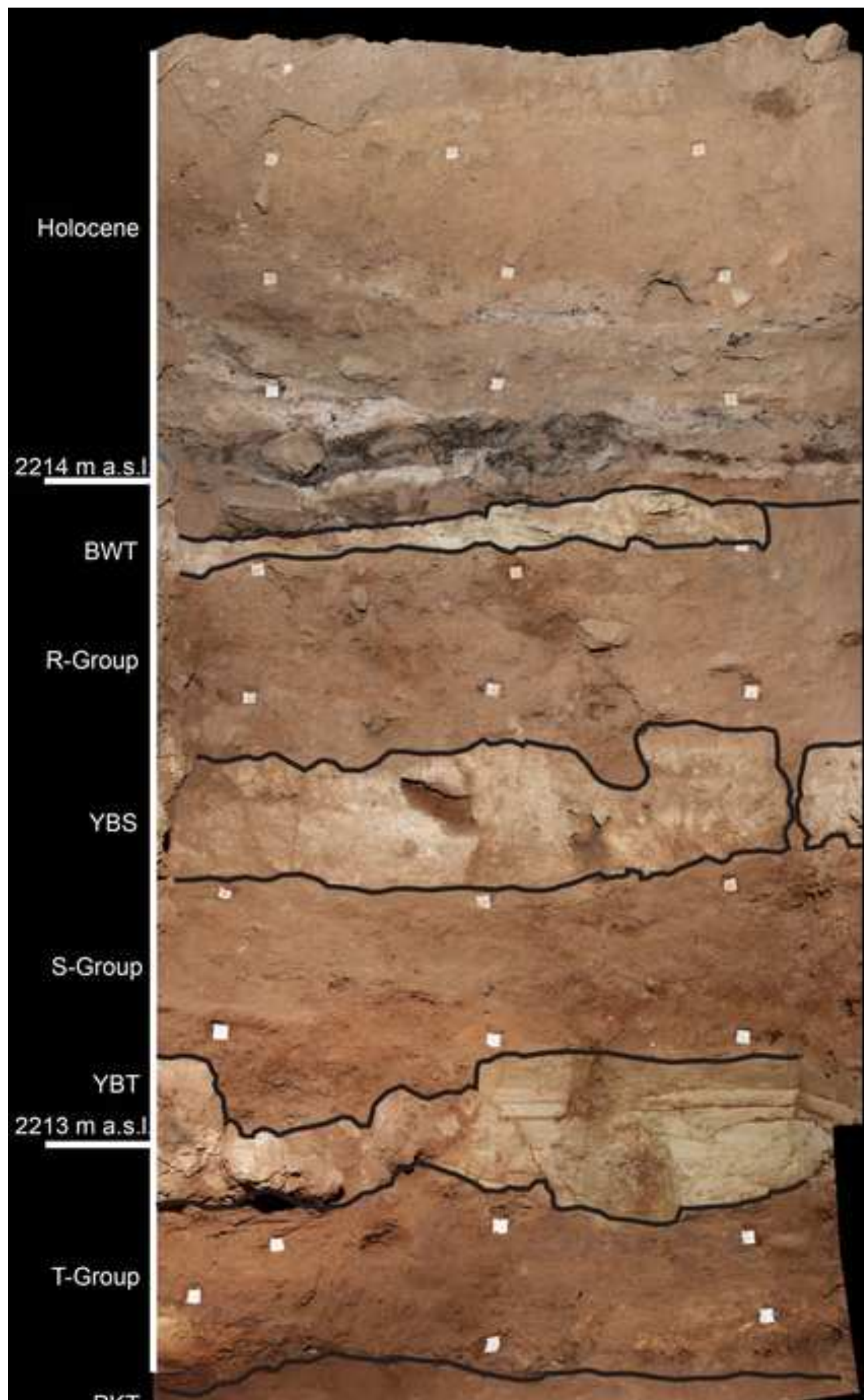

PKT 
Figure 4

Click here to download high resolution image

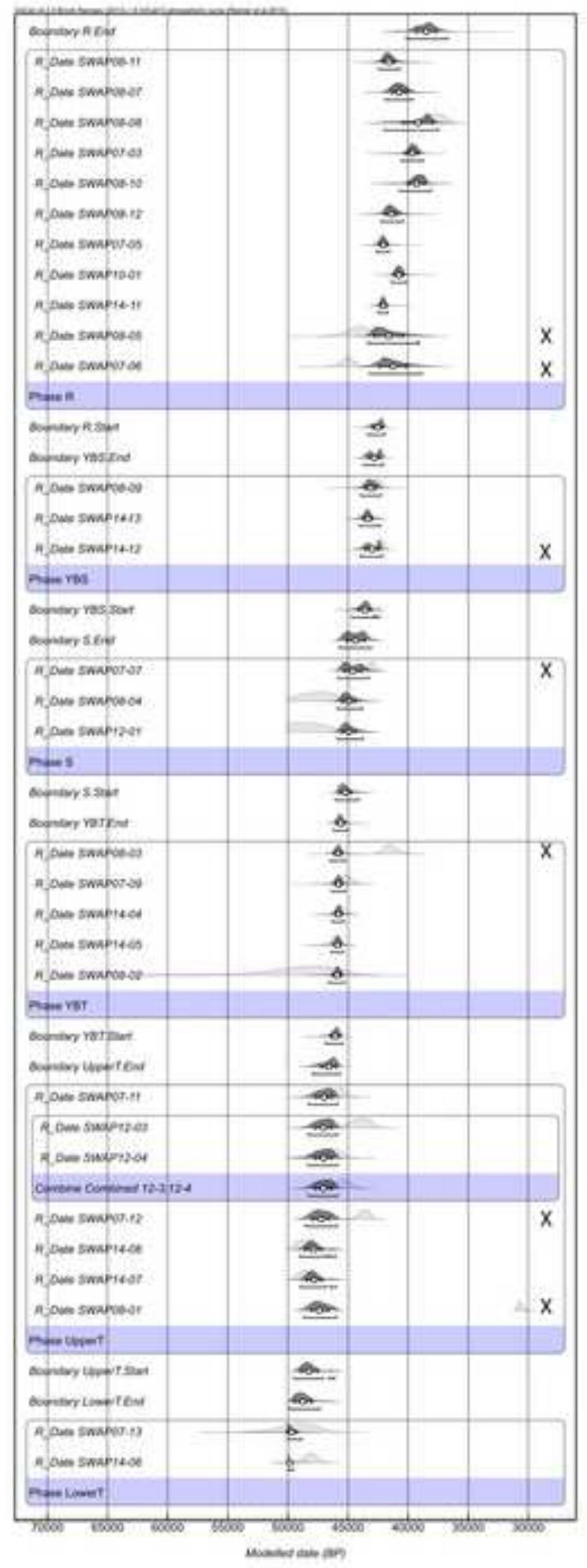

$$
\text { . }
$$

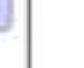

. 
Click here to download high resolution image

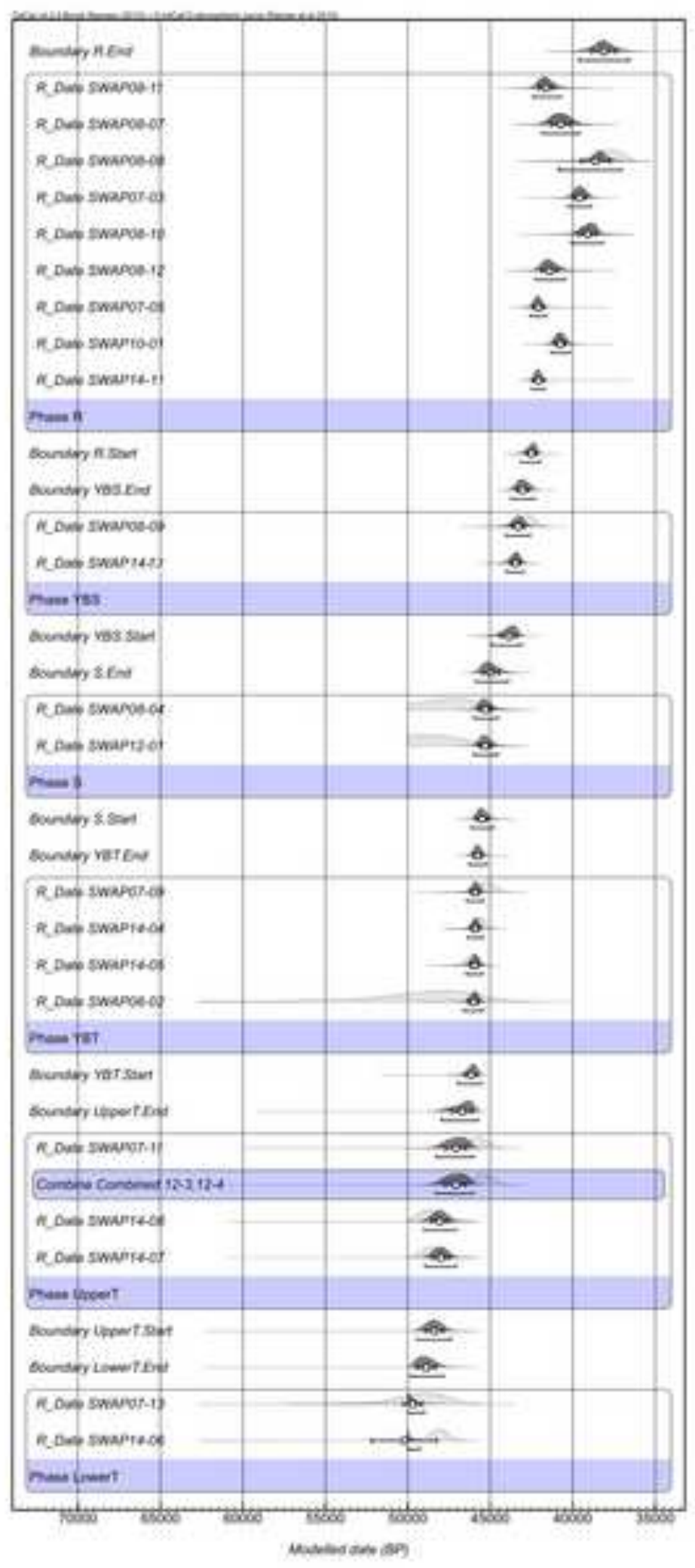

